\title{
Multi-locus phylogeny of the genus Curvularia and description of ten new species
}

\author{
Y. Marin-Felix ${ }^{1,2}$ - M. Hernández-Restrepo ${ }^{1}$ • P. W. Crous ${ }^{1,3,4,5}$ \\ Received: 17 October 2019 / Revised: 11 March 2020 / Accepted: 12 March 2020 \\ (C) The Author(s) 2020
}

\begin{abstract}
Curvularia is a cosmopolitan genus that includes species associated with plants, animals and humans, several of which are of clinical significance. Some of these species are important pathogens of grasses, causing devastating diseases on cereal crops in the family Poaceae. In the present multi-locus study, ex-type and reference strains of Curvularia, as well as several strains deposited in the CBS culture collection of the Westerdijk Fungal Biodiversity Institute, were included. Based on ITS, GAPDH and TEF1 sequences, as well as phenotypic data, ten new species are described and illustrated: C. arcana, C. austriaca, C. canadensis, C. ellisii, C. pseudoclavata, C. pseudoellisii, C. pseudointermedia, C. pseudoprotuberata, C. siddiquii and C. tribuli. Moreover, the new combinations $C$. cactivora and C. patereae are proposed, and an epitype for $C$. oryzae-sativae is designated. In addition, illustrations and descriptions are provided for C. cactivora, C. ellisii, C. crassiseptata, C. neergaardii, C. oryzae, C. oryzae-sativae, C. protuberata and C. verruciformis. The description of $C$. pseudobrachyspora is emended, and its host and distribution records are updated.
\end{abstract}

Keywords Bipolaris $\cdot$ Drechslera $\cdot$ Dothideomycetes $\cdot$ Helminthosporioid fungi $\cdot$ Human and plant pathogens

\section{Introduction}

Curvularia is a genus with a worldwide distribution that includes pathogens or saprobes of a wide range of plant hosts. Species occur mainly on members of the family Poaceae and represent important pathogens of grass and staple crops, including rice, maize, wheat and sorghum. Other hosts are

Section Editor: Gerhard Rambold

Y. Marin-Felix

Yasmina.MarinFelix@helmholtz-hzi.de

1 Westerdijk Fungal Biodiversity Institute, P.O. Box 85167, 3508 AD Utrecht, The Netherlands

2 Department of Microbial Drugs, Helmholtz Centre for Infection Research, Inhoffenstrasse 7, 38124 Brunswick, Germany

3 Department of Biochemistry, Genetics and Microbiology, Forestry and Agricultural Biotechnology Institute (FABI), University of Pretoria, Pretoria 0002, South Africa

4 Microbiology, Department of Biology, Utrecht University, Padualaan 8, 3584 CH Utrecht, The Netherlands

5 Laboratory of Phytopathology, Wageningen University and Research Centre (WUR), Droevendaalsesteeg 1, 6708PB Wageningen, The Netherlands genera belonging to Actinidiaceae, Aizoaceae, Caricaceae, Convolvulaceae, Fabaceae, Iridaceae, Lamiaceae, Lythraceae, Oleaceae, Polygonaceae and Rubiaceae (Sivanesan 1987; Manamgoda et al. 2015; Marin-Felix et al. 2017a, b; Tan et al. 2018). Curvularia also includes emerging opportunistic pathogens of humans that cause respiratory tract, cutaneous, cerebral and corneal infections, mainly in immunocompromised patients, e.g. C. chlamydospora and C. lunata (Carter and Boudreaux 2004; Madrid et al. 2014). Species such as C. spicifera, C. hawaiiensis, C. australiensis and $C$. lunata were not only isolated from human specimens (da Cunha et al. 2013; Manamgoda et al. 2015), but are also regarded as causal agents of animal and human diseases (de Hoog et al. 2011). Recently, two additional species, C. hominis and C. tuberculata, have been proven to be causal agents of keratitis (Miqueleiz Zapatero et al. 2018) and a human disseminated phaeohyphomycosis (Vasikasin et al. 2019). Curvularia species can also be found in other substrates, i.e. air ( $C$. aeria and $C$. pallescens; Manamgoda et al. 2015), aquatic environments ( $C$. robusta and C. senegalensis; Verma et al. 2013) and soil (C. soli and C. spicifera; Marin-Felix et al. 2017a; Tan et al. 2018).

Curvularia is characterised by the production of brown distoseptate conidia, usually with paler terminal cells and 
inordinately enlarged intermediate cells, which contributes to its characteristic curvature. The curvature of the conidia is the main difference to the similar genus Bipolaris, since in the latter the curvature, when present, is throughout the length of the conidium. In Bipolaris, conidia are usually also longer than in Curvularia (Sivanesan 1987; Marin-Felix et al. 2017a). However, both genera include species that exhibit intermediate conidial characters (Manamgoda et al. 2012), making sequence data essential for proper species delimitation. In this context, several studies based on the internal transcribed spacer regions and intervening 5.8S nrRNA gene (ITS), large subunit of the rDNA (LSU) and partial fragments of the glyceraldehyde-3-phosphate dehydrogenase (GAPDH) and the translation elongation factor 1- $\alpha$ (TEF1) genes have been performed, resulting in several species being transferred from one genus to another (Manamgoda et al. 2012, 2014; Tan et al. 2014). The Drechslera asexual morph of Pyrenophora, as well as species of Exserohilum and Johnalcornia, is also similar to Bipolaris and Curvularia (Tan et al. 2014; Hernández-Restrepo et al. 2018; Marin-Felix et al. 2019). Some Exserohilum species can be easily distinguished from the other three genera by the production of conidia with distinctly protruding hila, but some species of Curvularia produce similar structures, leading to wrong identifications (Hernández-Restrepo et al. 2018). Pyrenophora differs from the other graminicolous genera by its muriform septate ascospores, but the asexual morph is similar to Curvularia, also leading to incorrect identifications (Marin-Felix et al. 2019). Johnalcornia can be distinguished by forming the second conidial septum in the apical cell and producing distinctive conidia-like chlamydospores (Tan et al. 2014). Cochliobolus, which is known as the sexual morph of Curvularia and Bipolaris, is characterised by brown or black, globose ascomata, bitunicate, cylindrical asci and filiform or flagelliform, hyaline ascospores, which are loosely arranged into a helix or parallel (Manamgoda et al. 2012). The only difference is the presence of stromata in some Curvularia species, a feature not observed in Bipolaris (Manamgoda et al. 2012). Because the sexual morph is rarely found in nature and difficult to induce in culture, it is of limited value to distinguish Bipolaris and Curvularia (Manamgoda et al. 2014, 2015). Species of both Curvularia and Bipolaris are therefore mainly differentiated based on their asexual morphs (Marin-Felix et al. 2017a).

Curvularia species are difficult to identify based only on morphology since many species share similar characters with overlapping dimensions. In order to get a proper delimitation and identification, several phylogenetic studies using ITS, GAPDH and TEF 1 have recently been published (Manamgoda et al. 2012, 2015; Tan et al. 2014, 2018; Marin-Felix et al. 2017a, b). In the revision of the genus carried out by Marin-Felix et al. (2017a), 74 species were accepted based on DNA sequence data. Subsequently, 31 novelties have been introduced (Hyde et al. 2017; Marin-Felix et al. 2017b; Tan et al. 2018; Dehdari et al. 2018; Heidari et al. 2018; Hernández-Restrepo et al. 2018; Liang et al. 2018; Mehrabi-Koushki et al. 2018; Tibpromma et al. 2018). Hitherto, 105 species are accepted in the genus based on DNA sequence data. Some of these species were described a long time ago, with descriptions and/or illustrations not being readily available. In that context, Manamgoda et al. (2015) revised the genus and provided updated data for ten species. One of the objectives of this study is therefore to further enlarge our knowledge on the diversity and taxonomy of Curvularia. Another problem remaining unresolved is the lack of molecular data for those species that have only been described based on morphology, causing many of them to be ignored by the scientific community. A second objective is thus to provide sequence data of the main markers used in molecular studies of Curvularia and to determine the taxonomic position of many of these previously described species.

\section{Materials and methods}

\section{Isolates and morphological analysis}

Strains deposited in the Westerdijk Fungal Biodiversity Institute (CBS) collection identified as Curvularia or related genera, i.e. Bipolaris, Exserohilum, Johnalcornia and Pyrenophora, were examined (Table 1). These strains were cultured on potato dextrose agar (PDA), which is the medium used in the recent revisions of the genus, at $25^{\circ} \mathrm{C}$ under an alternating 12-h UV light/ dark regime to induce sporulation. When the cultures were mature, the fertile fungal structures were mounted and measured in lactic acid, with at least 30 measurements of each structure. The strains that did not produce reproductive structures on PDA were also cultured on $2 \%$ malt extract agar (MEA), oatmeal agar (OA) and synthetic nutrient-poor agar (SNA) (Crous et al. 2019) with pieces of sterile maize leaves in order to induce sporulation. Observations and photomicrographs were obtained with a Nikon SMZ1500 dissecting microscope, and with a Nikon eclipse Ni compound microscope, using a DS-Ri2 digital camera (Nikon, Tokyo, Japan) and NIS-Elements imaging software v. 4.20 .

Culture descriptions were done by incubating each isolate on three PDA plates in the dark. After a week, colony diameters were measured, colony morphologies described and the colours rated using the colour chart of Rayner (1970). Taxonomic novelties and typifications were registered in MycoBank (www.MycoBank.org; Crous et al. 2004).

\section{DNA isolation and amplification}

Genomic DNA was extracted and purified directly from fungal colonies growing on MEA according to the UltraClean ${ }^{\mathrm{TM}}$ 
Table 1 Details of isolates included in phylogenetic analyses. GenBank accession numbers in bold were newly generated in this study. Novelties are indicated in bold italic

\begin{tabular}{|c|c|c|c|c|c|c|}
\hline \multirow[t]{2}{*}{ Species } & \multirow[t]{2}{*}{ Isolates $^{\mathrm{a}}$} & \multirow[t]{2}{*}{ Country } & \multirow[t]{2}{*}{ Substrate } & \multicolumn{3}{|c|}{ GenBank accession numbers ${ }^{\mathrm{b}}$} \\
\hline & & & & ITS & $G A P D H$ & $T E F 1$ \\
\hline Bipolaris maydis & CBS $136.29^{\mathrm{PT}}$ & Japan & Zea mays & KJ909769 & KM034845 & KM093793 \\
\hline B. panici-miliacei & CBS $199.29^{\mathrm{LT}}$ & Japan & Panicum miliaceum & KJ909773 & KM042896 & KM093788 \\
\hline B. peregianensis & DAOM 221998 & Australia & Cynodon dactylon & KJ922393 & KM034849 & KM093797 \\
\hline B. sorokiniana & CBS 110.14 & USA & Hordeum sp. & KJ922381 & KM034822 & KM093763 \\
\hline Curvularia aeria & CBS $294.61^{\mathrm{T}}$ & Brazil & Air & HE861850 & HF565450 & - \\
\hline C. affinis & CBS $154.34^{\text {SynT }}$ & Indonesia & Unknown & KJ909780 & KM230401 & KM196566 \\
\hline C. ahvazensis & CBS $144673^{\mathrm{T}}$ & Iran & Zinnia elegans rotten roots & KX139029 & MG428693 & MG428686 \\
\hline C. akaii & CBS 317.86 & Japan & Themada triandra & KJ909782 & KM230402 & KM196569 \\
\hline C. akaiiensis & BRIP $16080^{\mathrm{IsoT}}$ & India & Unknown & KJ415539 & KJ415407 & KJ415453 \\
\hline C. alcornii & MFLUCC $10-0703^{\mathrm{T}}$ & Thailand & Zea sp. & JX256420 & JX276433 & JX266589 \\
\hline C. americana & UTHSC $08-3414^{\mathrm{T}}$ & USA & Human ankle & HE861833 & HF565488 & - \\
\hline C. arcana & CBS $127224^{\mathrm{T}}$ & Unknown & Unknown & MN688801 & MN688828 & MN688855 \\
\hline C. asiatica & MFLUCC $10-0711^{\mathrm{T}}$ & Thailand & Panicum sp. & JX256424 & JX276436 & JX266593 \\
\hline C. australiensis & BRIP $12044^{\mathrm{T}}$ & Australia & Oryza sativa & KJ415540 & KJ415406 & KJ415452 \\
\hline C. australis & BRIP $12521^{\mathrm{T}}$ & Australia & Sporobolus sp. & KJ415541 & KJ415405 & KJ415451 \\
\hline \multirow[t]{3}{*}{ C. austriaca } & CBS $102694^{\mathrm{T}}$ & Austria & $\begin{array}{l}\text { Nasal cavity of patient } \\
\text { with sinusitis }\end{array}$ & MN688802 & MN688829 & MN688856 \\
\hline & UTHSC 08-2957 & USA & Corneal ulcer & HE861846 & HF565456 & - \\
\hline & UTHSC 09-3510 & USA & Peritoneal dialysis fluid & HE861847 & HF565458 & - \\
\hline C. bannonii & BRIP $16732^{\text {IsoT }}$ & USA & Jacquemontia tamnifolia & KJ415542 & KJ415404 & KJ415450 \\
\hline C. beasleyi & BRIP $10972^{\mathrm{T}}$ & Australia & Chloris gayana & MH414892 & MH433638 & MH433654 \\
\hline C. beerburrumensis & BRIP $12942^{\mathrm{T}}$ & Australia & Eragrostis bahiensis & MH414894 & MH433634 & MH433657 \\
\hline C. boeremae & IMI $164633^{\mathrm{T}}$ & India & Portulaca oleracea & MH414911 & MH433641 & - \\
\hline C. bothriochloae & BRIP $12522^{\mathrm{T}}$ & Australia & Bothriochloa bladhii & KJ415543 & KJ415403 & KJ415449 \\
\hline C. brachyspora & CBS 186.50 & India & Soil & KJ922372 & KM061784 & KM230405 \\
\hline C. buchloes & CBS $246.49^{\mathrm{T}}$ & USA & Buchloë dactyloides & KJ909765 & KM061789 & KM196588 \\
\hline \multirow[t]{5}{*}{ C. cactivora } & CBS $580.74^{\mathrm{R}}$ & Republic of Suriname & Member of Cactaceae & MN688803 & MN688830 & MN688857 \\
\hline & Strain 737 & USA & Hylocereus undatus & HM598679 & HM598682 & - \\
\hline & Strain 738 & USA & Hylocereus undatus & HM598678 & HM598681 & - \\
\hline & Strain 739 & USA & Hylocereus undatus & HM598677 & HM598680 & - \\
\hline & DB13GEN09 & Italy & $\begin{array}{l}\text { Cereus peruvianus } \\
\text { var. monstruosus }\end{array}$ & KF041822 & - & - \\
\hline C. canadensis & CBS $109239^{\mathrm{T}}$ & Canada & Overwintered grass & MN688804 & MN688831 & MN688858 \\
\hline C. caricae-papayae & CBS $135941^{\mathrm{T}}$ & India & Carica papaya & HG778984 & HG779146 & - \\
\hline C. chiangmaiensis & CPC $28829^{\mathrm{T}}$ & Thailand & Zea mays & MF490814 & MF490836 & MF490857 \\
\hline C. chlamydospora & UTHSC $07-2764^{\mathrm{T}}$ & USA & Toe nail & HG779021 & HG779151 & - \\
\hline C. chonburiensis & MFLUCC $16-0375^{\mathrm{T}}$ & Thailand & dead leaf of Pandanus sp. & MH275055 & MH41274 & - \\
\hline C. clavata & BRIP 61680b & Australia & Oryza rufipogon & KU552205 & KU552167 & KU552159 \\
\hline C. coatesiae & BRIP $24261^{\mathrm{T}}$ & Australia & Litchi chinensis & MH414897 & MH433636 & MH433659 \\
\hline C. coicis & CBS $192.29^{\text {SynT }}$ & Japan & Coix lacryma & JN192373 & JN600962 & JN601006 \\
\hline C. colbranii & BRIP $13066^{\mathrm{T}}$ & Australia & Crinum zeylanicum & MH414898 & MH433642 & MH433660 \\
\hline C. crassiseptata & CBS $503.90^{\mathrm{T}}$ & Nigeria & Plant material & LT631310 & LT715882 & MN688859 \\
\hline C. crustacea & BRIP $13524^{\mathrm{ET}}$ & Indonesia & Sporobulus sp. & KJ415544 & KJ415402 & KJ415448 \\
\hline C. cymbopogonis & CBS 419.78 & The Netherlands & Yucca sp. & HG778985 & HG779129 & HG779163 \\
\hline C. dactylocteniicola & $\mathrm{CPC} 28810^{\mathrm{T}}$ & Thailand & Dactyloctenium aegyptium & MF490815 & MF490837 & MF490858 \\
\hline C. dactyloctenii & BRIP $12846^{\mathrm{T}}$ & Australia & Dactyloctenium radulans & KJ415545 & KJ415401 & KJ415447 \\
\hline \multirow[t]{2}{*}{ C. ellisii } & CBS $193.62^{\mathrm{T}}$ & Pakistan & Air & JN192375 & JN600963 & JN601007 \\
\hline & CBS 127083 & Australia & Dactyloctenium aegyptium & MN688805 & MN688832 & MN688860 \\
\hline C. eragrostidicola & BRIP $12538^{\mathrm{T}}$ & Australia & Eragrostis pilosa & MH414899 & MH433643 & MH433661 \\
\hline C. eragrostidis & CBS 189.48 & Indonesia & Sorghum sp. & HG778986 & HG779154 & HG779164 \\
\hline C. geniculata & CBS 187.50 & Indonesia & Unknown seed & KJ909781 & KM083609 & KM230410 \\
\hline C. gladioli & CBS 210.79 & Romania & Gladiolus sp. & HG778987 & HG779123 & - \\
\hline C. graminicola & BRIP $23186^{\mathrm{T}}$ & Australia & Unknown & JN192376 & JN600964 & JN601008 \\
\hline C. "gudauskasii" & DAOMC 165085 & Tanzania & Triticum aestivum & AF071338 & - & - \\
\hline C. harveyi & BRIP $57412^{\mathrm{IsoT}}$ & Australia & Triticum aestivum & KJ415546 & KJ415400 & KJ415446 \\
\hline C. hawaiiensis & BRIP $11987^{\text {IsoLT }}$ & USA & Oryza sativa & KJ415547 & KJ415399 & KJ415445 \\
\hline C. heteropogonicola & BRIP $14579^{\text {IsoT }}$ & India & Heteropogon contortus & KJ415548 & KJ415398 & KJ415444 \\
\hline C. heteropogonis & CBS $284.91^{\mathrm{T}}$ & Australia & Heteropogon contortus & JN192379 & JN600969 & JN601013 \\
\hline
\end{tabular}


Table 1 (continued)

\begin{tabular}{|c|c|c|c|c|c|c|}
\hline \multirow[t]{2}{*}{ Species } & \multirow[t]{2}{*}{ Isolates $^{\mathrm{a}}$} & \multirow[t]{2}{*}{ Country } & \multirow[t]{2}{*}{ Substrate } & \multicolumn{3}{|c|}{ GenBank accession numbers ${ }^{\mathrm{b}}$} \\
\hline & & & & ITS & $G A P D H$ & $T E F 1$ \\
\hline C. hominis & CBS $136985^{\mathrm{T}}$ & USA & Homo sapiens & HG779011 & HG779106 & - \\
\hline C. homomorpha & CBS $156.60^{\mathrm{T}}$ & USA & Air & JN192380 & JN600970 & JN601014 \\
\hline C. inaequalis & CBS $102.42^{\mathrm{T}}$ & France & Sand dune soil & KJ922375 & KM061787 & KM196574 \\
\hline C. intermedia & CBS 334.64 & USA & Avena versicolor & HG778991 & HG779155 & HG779169 \\
\hline C. ischaemi & CBS $630.82^{\mathrm{T}}$ & New Zealand & Ischaemum indicum & JX256428 & JX276440 & - \\
\hline C. kenpeggii & BRIP $14530^{\mathrm{T}}$ & Australia & Triticum aestivum & MH414900 & MH433644 & MH433662 \\
\hline C. kusanoi & CBS 137.29 & Japan & Eragrostis major & JN192381 & - & JN601016 \\
\hline C. lamingtonensis & BRIP $12259^{\mathrm{T}}$ & Australia & Microlaena stipoides & MH414901 & MH433645 & MH433663 \\
\hline C. lunata & CBS $730.96^{\mathrm{NT}}$ & USA & Lung biopsy & JX256429 & JX276441 & JX266596 \\
\hline C. malina & CBS $131274^{\mathrm{T}}$ & USA & Zoysia matrella & JF812154 & KP153179 & KR493095 \\
\hline C. mebaldsii & BRIP $12900^{\mathrm{T}}$ & Australia & Cynodon transvaalensis & MH414902 & MH433647 & MH433664 \\
\hline C. micropus & CBS $127235^{\mathrm{ET}}$ & USA & Paspalum notatum & HE792934 & LT715859 & - \\
\hline C. microspora & GUCC $6272^{\mathrm{T}}$ & China & Hippeastrum striatum leaf spot & MF139088 & MF139097 & MF139115 \\
\hline C. miyakei & CBS $197.29^{\text {SynT }}$ & Japan & Eragrostis pilosa & KJ909770 & KM083611 & KM196568 \\
\hline C. mosaddeghii & IRAN $3131 C^{\mathrm{T}}$ & Iran & Syzygium cumini leaf spot & MG846737 & MH392155 & MH392152 \\
\hline C. muehlenbeckiae & CBS $144.63^{\mathrm{T}}$ & India & Muehlenbeckia sp. & HG779002 & HG779108 & - \\
\hline \multirow[t]{3}{*}{ C. neergaardii } & BRIP $12919^{\text {IsoT }}$ & Ghana & Oryza sativa & KJ415550 & KJ415397 & KJ415443 \\
\hline & CBS 276.91 & Australia & Unknown & MN688806 & MN688833 & MN688861 \\
\hline & CBS 277.91 & Australia & Unknown & MN688807 & MN688834 & MN688862 \\
\hline C. neoindica & IMI $129790^{\mathrm{T}}$ & India & Brassica nigra & NR_158450 & MH433649 & MH433667 \\
\hline C. nicotiae & CBS $655.74^{\mathrm{IsoT}}$ & Algeria & Desert soil & $\mathrm{KJ} 4 \overline{1} 15551$ & KJ415396 & KJ415442 \\
\hline C. nodosa & CPC $28800^{\mathrm{T}}$ & Thailand & Digitaria ciliaris & MF490816 & MF490838 & MF490859 \\
\hline C. nodulosa & CBS 160.58 & USA & Eleusine indica & JN601033 & JN600975 & JN601019 \\
\hline C. oryzae & CBS $169.53^{\text {IsoT }}$ & Vietnam & Oryza sativa & KP400650 & KP645344 & KM196590 \\
\hline C. oryzae-sativae & CBS $127725^{\mathrm{ET}}$ & Argentina & Oryza sativa & MN688808 & MN688835 & MN688863 \\
\hline C. ovariicola & CBS $470.90^{\mathrm{T}}$ & Australia & Eragrostis interrupta & MN688809 & MN688836 & - \\
\hline C. pandanicola & MFLUCC $15-0746^{\mathrm{T}}$ & Thailand & Dead leaf of Pandanus sp. & MH275056 & MH412748 & MH412763 \\
\hline C. papendorfii & CBS $308.67^{\mathrm{T}}$ & South Africa & Acacia karroo & KJ909774 & KM083617 & KM196594 \\
\hline \multirow[t]{2}{*}{ C. pallescens } & CBS $156.35^{\mathrm{T}}$ & Java & Air & KJ922380 & KM083606 & KM196570 \\
\hline & CBS 859.73 & Chile & Volcanic ash soil & HE861848 & HF565455 & - \\
\hline C. palmicola & MFLUCC $14-0404^{\mathrm{T}}$ & Thailand & $\begin{array}{l}\text { Dead branches of } \\
\quad \text { Acoelorrhaphe wrightii }\end{array}$ & MF621582 & - & - \\
\hline C. patereae & CBS $198.87^{\mathrm{T}}$ & Argentina & Triticum durum seed & MN688810 & MN688837 & MN688864 \\
\hline C. penniseti & CBS 528.70 & Unknown & Pennisetum sp. seed & MN688811 & MN688838 & - \\
\hline C. perotidis & CBS $350.90^{\mathrm{T}}$ & Australia & Perotis rara & JN192385 & KJ415394 & JN601021 \\
\hline C. petersonii & BRIP $14642^{\mathrm{T}}$ & Australia & Dactyloctenium aegyptium & MH414905 & MH433667 & MH433668 \\
\hline C. pisi & CBS $190.48^{\mathrm{T}}$ & Canada & Pisum sativum & KY905678 & KY905690 & KY905697 \\
\hline C. platzii & BRIP $27703 b^{T}$ & Australia & Cenchrus clandestinum & MH414906 & MH433651 & MH433669 \\
\hline C. portulacae & BRIP $14541^{\text {IsoT }}$ & USA & Portulaca oleracea & KJ415553 & KJ415393 & KJ415440 \\
\hline C. prasadii & CBS $143.64^{\mathrm{T}}$ & India & Jasminum sambac & KJ922373 & KM061785 & KM230408 \\
\hline C. protuberata & CBS $376.65^{\mathrm{T}}$ & Scotland & Deschampsia flexuosa leaf & KJ922376 & KM083605 & KM196576 \\
\hline \multirow[t]{8}{*}{ C. pseudobrachyspora } & CPC $28808^{\mathrm{T}}$ & Thailand & Eleusine indica & MF490819 & MF490819 & MF490819 \\
\hline & CBS 207.59 & Unknown & Unknown & MN688812 & MN688839 & MN688865 \\
\hline & CBS 533.70 & Denmark & Pennisetum sp. seed & MN688813 & MN688840 & MN688866 \\
\hline & CBS 336.64 & USA & Trisetum $\mathrm{sp.}$ & MN688814 & MN688841 & - \\
\hline & CBS 337.64 & USA & Agropyron repens & MN688815 & MN688842 & MN688867 \\
\hline & CBS 339.64 & USA & Pennisetum glaucum & MN688816 & MN688843 & MN688868 \\
\hline & MFLUCC 10-0739 & Thailand & Oryza sativa & JX256443 & JX276454 & JX266603 \\
\hline & HNWN001 & China & Areca catech $u$ leaf & MH516132 & MH516133 & MH516134 \\
\hline C. pseudoclavata & CBS $539.70^{\mathrm{T}}$ & Denmark & Oryza sativa seeds & MN688817 & MN688844 & MN688869 \\
\hline C. pseudoellisii & CBS $298.80^{\mathrm{T}}$ & Sudan & Sorghum bicolor seed & MN688818 & MN688845 & MN688870 \\
\hline \multirow[t]{2}{*}{ C. pseudointermedia } & CBS $553.89^{\mathrm{T}}$ & Brazil & Cultivated pasture soil & MN688819 & MN688846 & MN688871 \\
\hline & CBS 188.61 & Guadeloupe & Decaying grass & MN688820 & MN688847 & MN688872 \\
\hline C. pseudolunata & UTHSC $09-2092^{\mathrm{T}}$ & USA & Nasal sinus & HE861842 & HF565459 & - \\
\hline \multirow[t]{2}{*}{ C. pseudoprotuberata } & CBS $385.69^{\mathrm{T}}$ & Canada & Soil under Thuja occidentalis & MN688821 & MN688848 & MN688873 \\
\hline & CBS 550.69 & Canada & Soil under Pinus strobus & MN688822 & MN688849 & MN688874 \\
\hline C. pseudorobusta & UTHSC 08-3458 & USA & Nasal sinus & HE861838 & HF565476 & - \\
\hline C. ravenelii & BRIP $13165^{\mathrm{T}}$ & Australia & Sporobolus fertilis & JN192386 & JN600978 & JN601024 \\
\hline C. reesii & BRIP $4358^{\mathrm{T}}$ & Australia & Air & MH414907 & MH433637 & MH433670 \\
\hline C. richardiae & BRIP $4371^{\text {IsoLT }}$ & Australia & Richardia brasiliensis & KJ415555 & KJ415391 & KJ415438 \\
\hline
\end{tabular}


Table 1 (continued)

\begin{tabular}{|c|c|c|c|c|c|c|}
\hline \multirow[t]{2}{*}{ Species } & \multirow[t]{2}{*}{ Isolates $^{\mathrm{a}}$} & \multirow[t]{2}{*}{ Country } & \multirow[t]{2}{*}{ Substrate } & \multicolumn{3}{|c|}{ GenBank accession numbers ${ }^{\mathrm{b}}$} \\
\hline & & & & ITS & $G A P D H$ & $T E F 1$ \\
\hline C. robusta & CBS $624.68^{\mathrm{IsoT}}$ & USA & Dichanthium annulatum & KJ909783 & KM083613 & KM196577 \\
\hline C. rouhanii & CBS $144674^{\mathrm{T}}$ & Iran & $\begin{array}{l}\text { Blighted leaves of } \\
\text { Syngonium vellozianum }\end{array}$ & KX139030 & MG428694 & MG428687 \\
\hline C. ryleyi & BRIP $12554^{\mathrm{T}}$ & Australia & Sporobulus creber & KJ415556 & KJ415390 & KJ415437 \\
\hline C. senegalensis & CBS 149.71 & Nigeria & Unknown & HG779001 & HG779128 & - \\
\hline C. sesuvi & Bp-Zj 01 & Unknown & Sesuvum sp. & EF175940 & - & - \\
\hline C. shahidchamranensis & IRAN $3133 C^{\mathrm{T}}$ & Iran & Soil & MH550084 & MH550083 & - \\
\hline C. sichuanensis & HSAUP II. $2650-1^{\mathrm{T}}$ & China & $\begin{array}{l}\text { Undetermined plant } \\
\text { of Gramineae }\end{array}$ & AB453881 & - & - \\
\hline \multirow[t]{2}{*}{ C. siddiquii } & CBS $196.62^{\mathrm{T}}$ & Pakistan & Air & MN688823 & MN688850 & - \\
\hline & CBS 142.78 & Egypt & Unknown & MN688824 & MN688851 & - \\
\hline C. soli & CBS $222.96^{\mathrm{T}}$ & Papua New Guinea & Soil & KY905679 & KY905691 & KY905698 \\
\hline C. sorghina & BRIP $15900^{\text {IsoT }}$ & Australia & Sorghum bicolor & KJ415558 & KJ415388 & KJ415435 \\
\hline C. spicifera & CBS 274.52 & Spain & Soil & JN192387 & JN600979 & JN601023 \\
\hline C. sporobolicola & BRIP $23040 b^{\mathrm{T}}$ & Australia & Sporobolus australasicus & MH414908 & MH433652 & MH433671 \\
\hline C. subpapendorfii & CBS $656.74^{\mathrm{T}}$ & Egypt & Desert soil & KJ909777 & KM061791 & KM196585 \\
\hline C. thailandica & MFLUCC $15-0747^{\mathrm{T}}$ & Thailand & Dead leaf of Pandanus sp. & MH275057 & MH412749 & MH412764 \\
\hline C. tribuli & CBS $126975^{\mathrm{T}}$ & South Africa & Tribulus terrestris leaf & MN688825 & MN688852 & MN688875 \\
\hline C. trifolii & CBS 173.55 & USA & Trifolium repens & HG779023 & HG779124 & - \\
\hline C. tripogonis & BRIP $12375^{\mathrm{T}}$ & Australia & Unknown & JN192388 & JN600980 & JN601025 \\
\hline C. tropicalis & BRIP $14834^{\text {IsoT }}$ & India & Coffea arabica & KJ415559 & KJ415387 & KJ415434 \\
\hline C. tsudae & ATCC $44764^{\mathrm{PT}}$ & Japan & Chloris gayana & KC424596 & KC747745 & KC503940 \\
\hline C. tuberculata & CBS $146.63^{\text {IsoT }}$ & India & Zea mays & JX256433 & JX276445 & JX266599 \\
\hline C. uncinata & CBS $221.52^{\mathrm{T}}$ & Vietnam & Oryza sativa & HG779024 & HG779134 & - \\
\hline C. variabilis & $\mathrm{CPC} 28815^{\mathrm{T}}$ & Thailand & Chloris barbata & MF490822 & MF490844 & MF490865 \\
\hline C. verruciformis & CBS 537.75 & New Zealand & $\begin{array}{l}\text { Lobibyx (masked plover) } \\
\text { feather }\end{array}$ & HG779026 & HG779133 & HG779211 \\
\hline C. verrucosa & CBS 422.93 & Cuba & Air & MN688826 & MN688853 & MN688876 \\
\hline C. verruculosa & CBS 150.63 & India & Punica granatum & KP400652 & KP645346 & KP735695 \\
\hline C. warraberensis & BRIP $14817^{\mathrm{T}}$ & Australia & Dactyloctenium aegyptium & MH414909 & MH433653 & MH433672 \\
\hline C. xishuangbannaensis & MFLUCC $17-2271^{\mathrm{T}}$ & Thailand & Dead leaf of Pandanus sp. & MH275058 & MH412750 & MH412765 \\
\hline Exserohilum rostratum & CBS 325.87 & USA & Homo sapiens & HE664035 & LT715898 & HE664082 \\
\hline E. turcicum & CBS $690.71^{\mathrm{ET}}$ & Germany & Zea mays & LT837487 & LT882581 & LT896618 \\
\hline \multirow[t]{2}{*}{ Johnalcornia aberrans } & CBS $510.91^{\mathrm{IsoT}}$ & Australia & Eragrostis parviflora & KJ415522 & KJ415424 & KJ415473 \\
\hline & CBS 281.91 & Australia & Unknown & MN688827 & MN688854 & MN688877 \\
\hline Pyrenophora phaeocomes & DAOMC 222769 & Switzerland & Calamagrostis villosa & JN943649 & - & DQ497607 \\
\hline P. poae & BRIP 10953 & Australia & Member of Poaceae & KJ415566 & KJ415380 & KJ415427 \\
\hline P. seminiperda & BRIP 10941 & Australia & Triticum aestivum & KJ415564 & KJ415382 & KJ415429 \\
\hline
\end{tabular}

${ }^{a}$ ATCC, American Type Culture Collection, Virginia, USA; BRIP, Queensland Plant Pathology Herbarium, Brisbane, Australia; $B p-Z j$, isolate housed in Biotechnology Institute, Zhejiang University, Hangzhou, China; $C B S$, Westerdijk Fungal Biodiversity Institute, Utrecht, the Netherlands; $C P C$, culture collection of Pedro Crous, housed at the Westerdijk Fungal Biodiversity Institute; DAOMC, Plant Research Institute, Department of Agriculture (Mycology), Ottawa, Canada; GUCC, Culture collection at the Department of Plant Pathology, Agriculture College, Guizhou University, China; HSAUP, Herbarium of the Department of Plant Pathology of Shandong Agricultural University, Shandong, China; IMI, International Mycological Institute, CABI-Bioscience, Egham, Bakeham Lane, UK; IRAN, Iranian Fungal Culture Collection, Iranian Research Institute of Plant Protection, Tehran, Iran; MFLUCC, Mae Fah Luang University Culture Collection, Chiang Ria, Thailand; UTHSC, Fungus Testing Laboratory, Department of Pathology at the University of Texas Health Science Center, San Antonio, Texas, USA; DB13GEN09, isolate housed in Italy; HNWN001, isolate housed in China; strains 737, 738, 739: isolates housed in Florida. ${ }^{\text {ET }}$, IsoT ${ }^{\text {IsoLT }},{ }^{\text {PT }},{ }^{\mathrm{R}}$, SynT ${ }^{\text {and }}{ }^{\mathrm{T}}$ indicate ex-epitype, ex-isotype, ex-isolectotype, ex-paratype, reference, ex-syntype and ex-type strains, respectively

${ }^{\mathrm{b}}$ ITS, internal transcribed spacers and intervening 5.8S nrDNA; GAPDH, partial glyceraldehyde-3-phosphate dehydrogenase gene; TEF1, partial translation elongation factor 1-alpha gene 
Microbial DNA Isolation kit (MoBio Laboratories, Inc., Solana Beach, CA, USA) and Wizard® Genomic DNA purification kit (Promega, Madison, USA) protocols.

The amplification of the ITS and fragments of the GAPDH and TEF1 genes was performed for the selected strains, according to White et al. (1990) (ITS) and Manamgoda et al. (2012) (GAPDH and TEF1).

\section{Phylogenetic study}

The phylogenetic analysis based on ITS, GAPDH and TEF1 was carried out, including strains available in the CBS collection and sequences of ex-type and reference strains of Curvularia spp. available in GenBank (Table 1). Each locus was aligned separately using MAFFT v. 7 (Katoh and Standley 2013) and manually adjusted in MEGA v. 6.06 (Tamura et al. 2013). The maximum likelihood (ML) and Bayesian inference (BI) were performed for the combined dataset using RAxML as was described by HernándezRestrepo et al. (2016). The sequences generated in this study were deposited in GenBank, and the alignments in TreeBASE (www.treebase.org, S23887).

\section{Results}

The lengths of the fragments of the three genes used in the combined dataset were $505 \mathrm{bp}$ (ITS), $477 \mathrm{bp}(G A P D H)$ and 892 bp (TEF1). The length of the final alignment was 1874 bp. The consensus tree obtained from the RAxML analysis of the combined dataset is shown in Fig. 1, which agreed with the topology of the Bayesian analysis. It includes RAxML bootstrap support (BS) and Bayesian posterior probability at the nodes. In the combined phylogenetic tree (Fig. 1), species of Curvularia formed a supported clade $(92 \% \mathrm{bs} / 1 \mathrm{pp})$ clearly separated from other graminicolous helminthosporioid genera included in the phylogenetic study, i.e. Bipolaris, Exserohilum, Johnalcornia and Pyrenophora.

Seventeen strains included in the phylogenetic study were located in ten independent branches distant from other species of Curvularia. The morphological study of these strains revealed enough differences to propose ten new species, i.e. C. arcana, C. austriaca, C. canadensis, C. ellisii, C. pseudoclavata, C. pseudoellisii, C. pseudointermedia, C. pseudoprotuberata, C. siddiquii and C. tribuli.

Interestingly, CBS 198.87, the ex-type strain of Drechslera patereae, was located in the main clade representing the genus Curvularia. Therefore, a new combination is proposed in the taxonomy section. Moreover, five different isolates identified as Bipolaris cactivora were located in a fully supported subclade (100\% bs/
$1 \mathrm{pp)}$ within the Curvularia clade. Based on sequence similarities and morphological data, the new combination C. cactivora is also proposed.

The ex-type isolate (CBS 193.62) of the currently invalid C. ellisii, which is validly redescribed below, and the isolate CBS 127083 (obtained from a sexual cross) were located in a well-supported clade ( $86 \% \mathrm{bs} / 1 \mathrm{pp})$.

Finally, seven strains, CBS 207.59, CBS 533.70, CBS 336.64, CBS 337.64, CBS 339.64, MFLUCC 10-0739 and HNWN001, were located in a clade $(89 \% \mathrm{bs} /-\mathrm{pp})$ together with CPC 28808, the ex-type strain of $C$. pseudobrachyspora. Strain CBS 533.70 was found to differ morphologically from the extype strain, and thus, the original description is herewith emended, and new host and distribution reports are included.

\section{Taxonomy}

Curvularia arcana Hern.-Restr. \& Y. Marín, sp. nov. Fig. 2. MB832460

Etymology. Name refers to the mystery of the origin of the ex-type strain.

Holotype. Unknown data, CBS H-24098.

Ex-type strain. CBS 127224.

Asexual morph on PDA Hyphae hyaline to pale brown, branched, septate, smooth-walled, 1-3 $\mu \mathrm{m}$. Conidiophores single or in small groups, semi- to macronematous, septate, sometimes reduced to conidiogenous cells, straight to flexuous, geniculate, branched, cell walls thicker than those of vegetative hyphae, mononematous, pale brown to brown, not swollen at the base, $8-93 \times 2-4 \mu \mathrm{m}$. Conidiogenous cells smooth-walled, terminal or intercalary, proliferating sympodially, pale brown to brown, subcylindrical to slightly swollen, 4-15 × 1.5-4 $\mu \mathrm{m}$. Conidia smooth-walled, straight, sometimes curved, ellipsoidal to ovoid, pale brown to brown, (1)3-4-distoseptate, 10.5-28 × 6-9(11.5) $\mu \mathrm{m}$; hila protruding, flat, darkened, thickened, 1-1.5 $\mu \mathrm{m}$ wide. Chlamydospores, microconidiation and sexual morph not observed.

Culture characteristics Colonies on PDA reaching 62-70 mm diam in 1 week, smoke grey to olivaceous black, with moderate aerial mycelium giving the colony a cottony appearance, margin fimbriate to lobate; reverse olivaceous black.

Notes In our phylogenetic study, C. arcana was located on an independent branch representing a new species (Fig. 1). Regrettably, no data about the ex-type strain are available. Curvularia arcana is located in a basal clade that includes C. intermedia and C. pseudointermedia (Fig. 1). For morphological differences, see notes under C. pseudointermedia.

Curvularia austriaca Y. Marín \& Crous, sp. nov. Fig. 3. MB830045

Etymology. Named after the country where the type material was collected, Austria. 


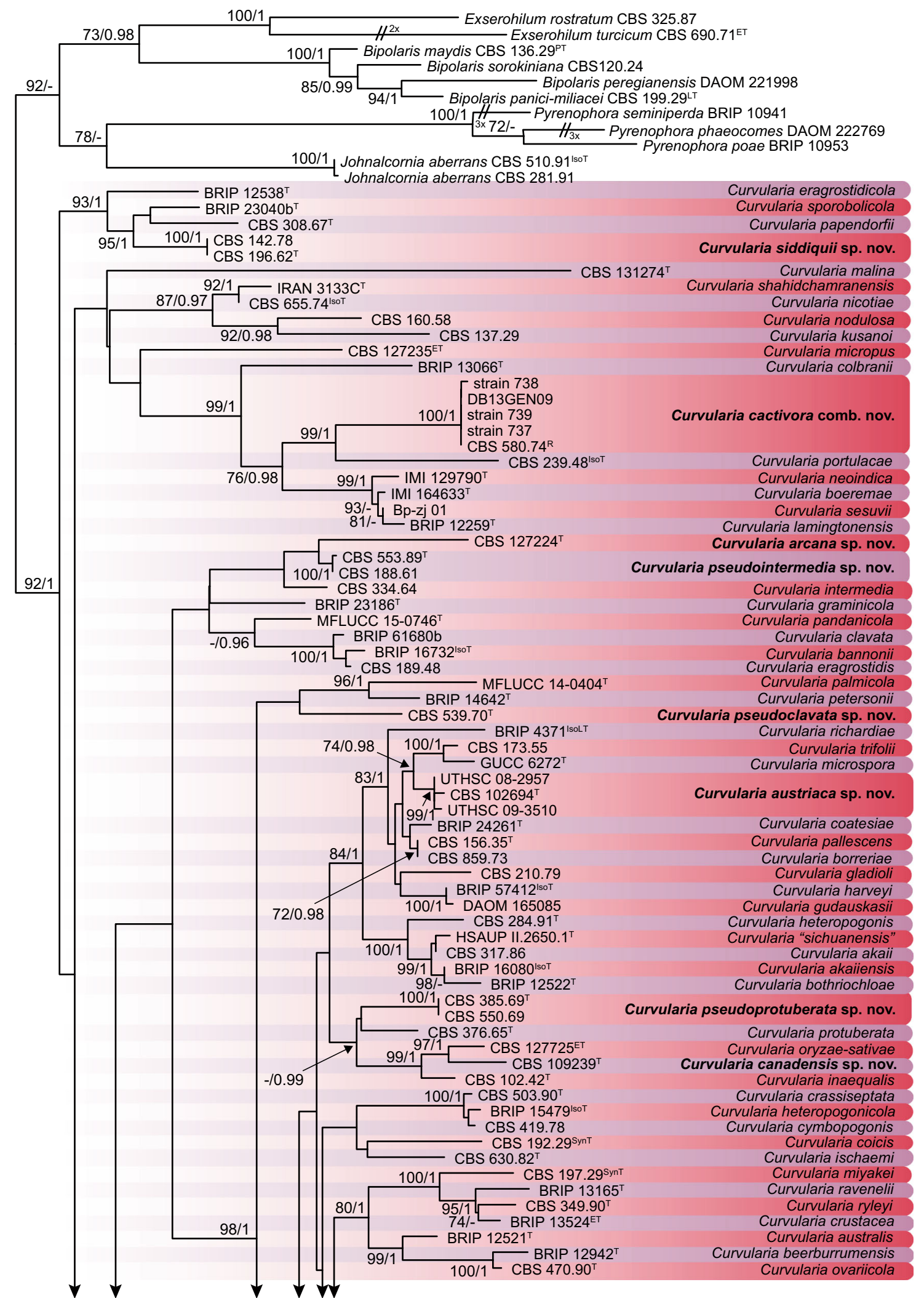

Fig. 1 RAxML phylogram obtained from the combined ITS, GAPDH and TEF 1, sequences of strains belonging to the genus Curvularia. The tree was rooted to other members of Pleosporaceae, i.e. Bipolaris spp., Exserohilum spp., Pyrenophora spp. and Johnalcornia aberrans. The novelties proposed in this study are shown in bold. RAxML bootstrap support (BS) values above $70 \%$ and Bayesian posterior probability scores above 0.95 are shown at the nodes. ${ }^{\mathrm{ET}},{ }^{\mathrm{IsoT}},{ }^{\mathrm{IsoLT}},{ }^{\mathrm{PT}},{ }^{\mathrm{R}},{ }^{\mathrm{SynT}}$ and $^{\mathrm{T}}$ indicate ex-epitype, ex-isotype, ex-isolectotype, ex-paratype, reference, exsyntype and ex-type strains, respectively 


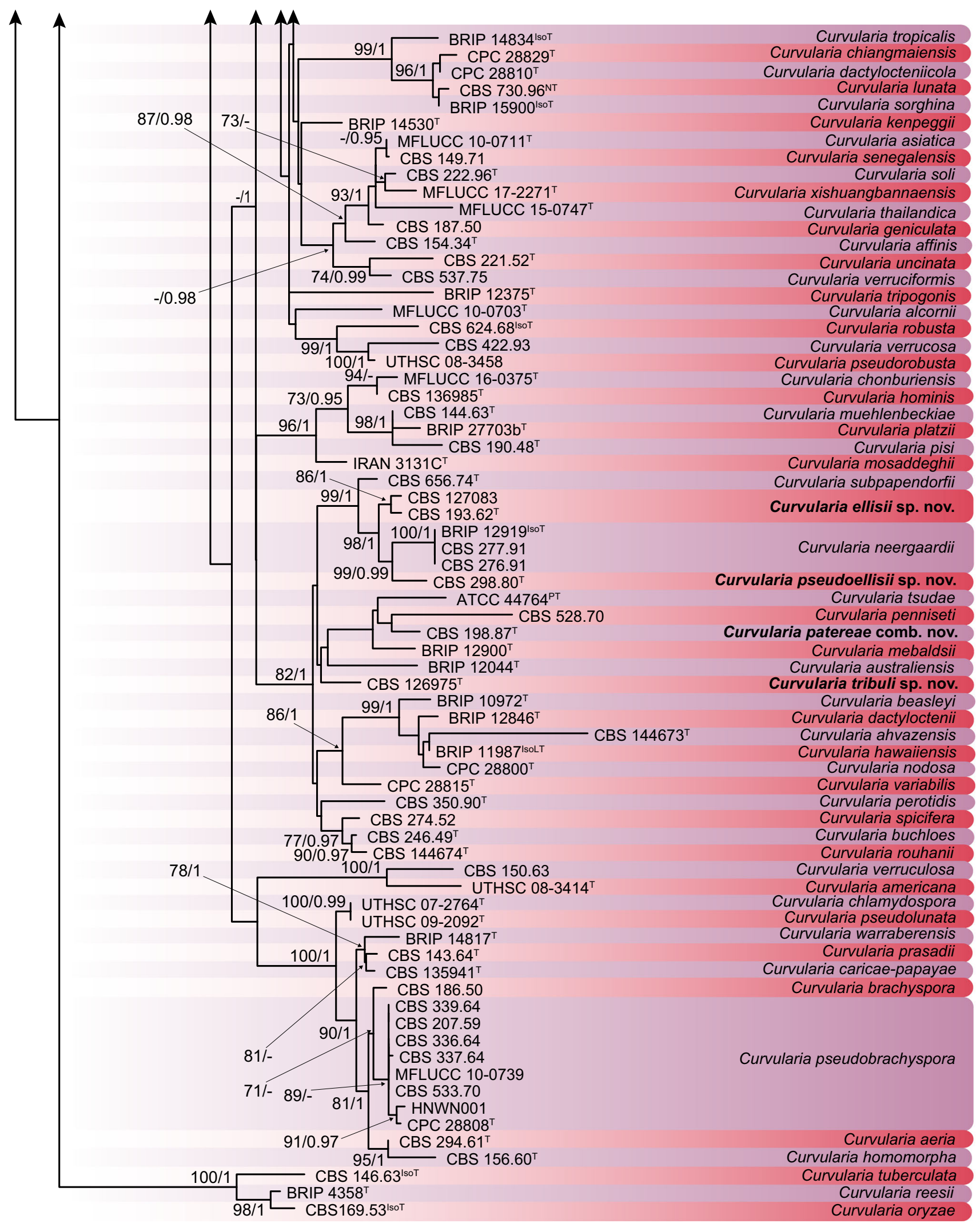

Fig. 1 (continued) 

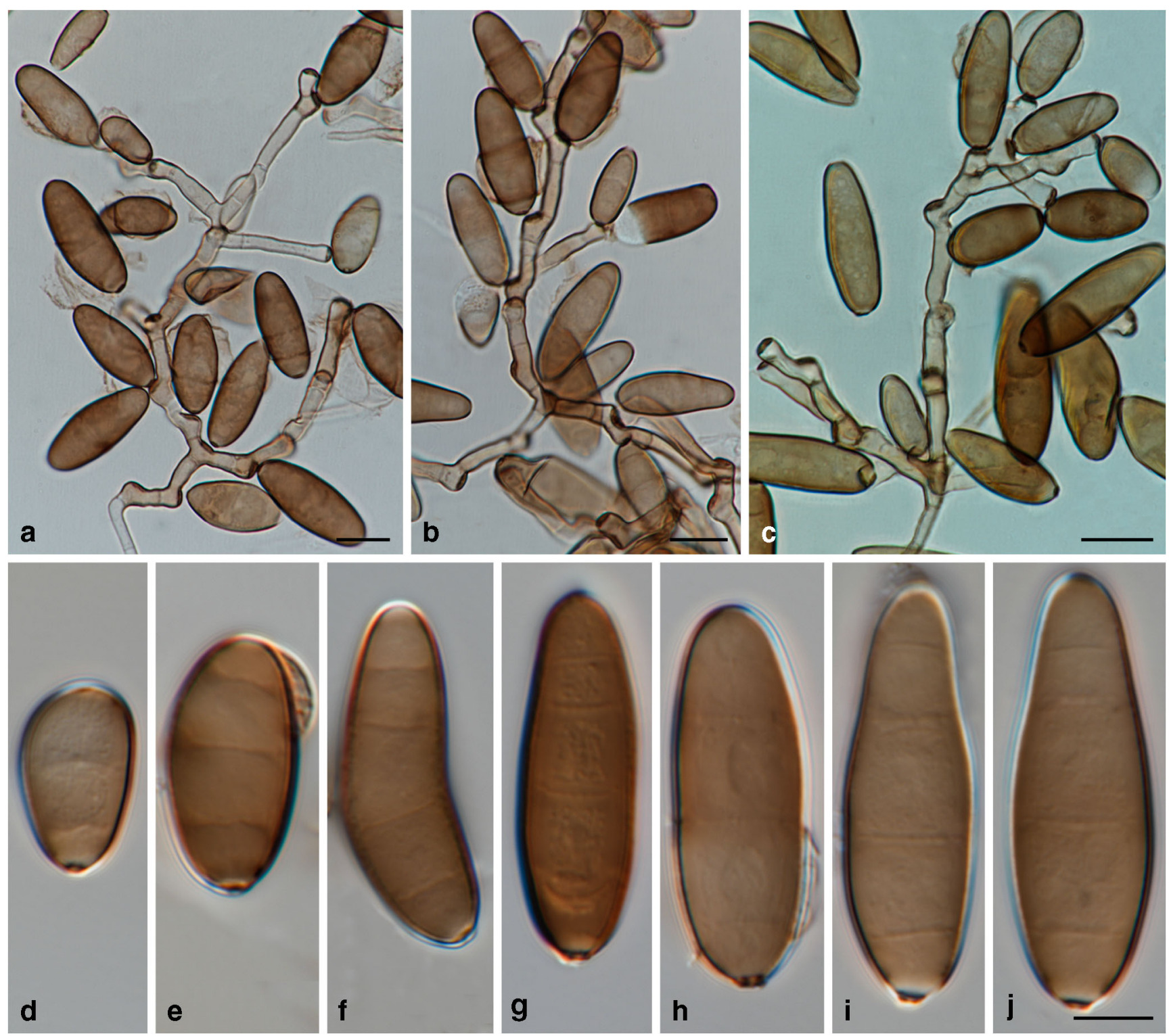

Fig. 2 Curvularia arcana (CBS 127224 ex-type). a-c Conidiophores, conidiogenous cells and conidia; $\mathbf{d}-\mathbf{g}$ conidia. Scale bars $\mathbf{a}-\mathbf{c}=10 \mu \mathrm{m} ; \mathbf{j}=5 \mu \mathrm{m}, \mathbf{j}$ applies to $\mathbf{d}-\mathbf{j}$

Holotype. Austria: Graz, from a nasal cavity of patient with sinusitis, 28 Aug. 1968, W. Buzina, CBS H-24091.

Ex-type strain. CBS 102694.

Additional material examined. USA: West Virginia, corneal ulcer, D.A. Sutton, UTHSC 08-2957 = FMR 11669. Washington, District of Columbia, peritoneal dialysis fluid, D.A. Sutton, UTHSC 09-3510 = FMR 11507.

Asexual morph on OA Hyphae subhyaline to pale brown, branched, septate, thick-walled, 2-4.5 $\mu \mathrm{m}$. Conidiophores arising in groups, mononematous, semi- to macronematous, septate, straight to flexuous, mostly geniculate at upper part, not swollen at the base, cell size not decreasing towards apex, rarely branched, cell walls thicker than those of vegetative hyphae, pale brown, rarely brown, not paler towards apex,
60-260 $\times 2.5-5(6.5) \mu \mathrm{m}$. Conidiogenous cells smoothwalled, terminal or intercalary, proliferating sympodially, pale brown, rarely brown, subcylindrical to slightly swollen, 5$13(14) \times 4-6 \mu \mathrm{m}$. Conidia smooth-walled to finely verruculose, straight or slightly curved, ellipsoidal to ovoid, middle cells slightly enlarged, pale brown to brown, apical and basal cells paler, (2)3-distoseptate, (20.5)23-32 × 7.512.5(13.5) $\mu \mathrm{m}$; hila protuberant, darkened, thickened, $2-$ $3 \mu \mathrm{m}$ wide. Chlamydospores, microconidiation and sexual morph not observed.

Culture characteristics Colonies on PDA reaching 75-90 mm diam in 1 week, luteous to orange, umber in the centre, with moderate aerial mycelium giving the colony a slightly cottony appearance, lobulate; reverse luteous to orange. 

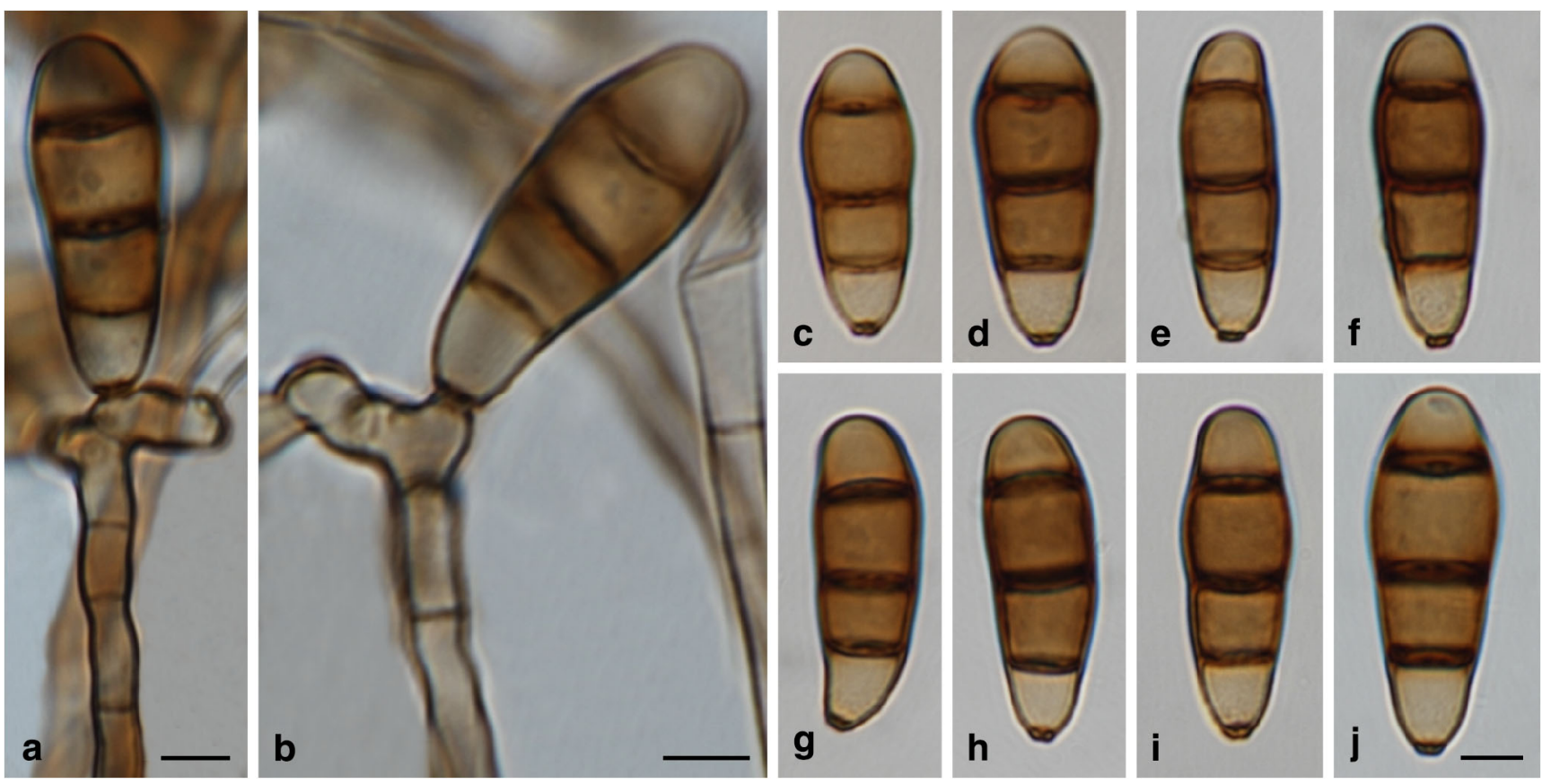

Fig. 3 Curvularia austriaca (CBS 102694 ex-type). a, b Conidiogenous cells and conidia; $\mathbf{c}-\mathbf{j}$ conidia. Scale bars $5 \mu$ m, j applies to $\mathbf{c}-\mathbf{j}$

Notes Curvularia austriaca is related to C. borreriae, C. coatesiae, C. microspora, C. pallescens and C. trifolii. These species all primarily produce 3 -distoseptate conidia. Curvularia coatesiae and C. microspora differ from C. austriaca in producing smaller conidia $[(20.5) 23-32 \times 7.5-12.5(13.5) \mu \mathrm{m}$ in C. austriaca vs (20)23-26(30) $\times(7) 8-9(10) \mu \mathrm{m}$ in C. coatesiae vs 4.5-11.5 × 2-6 $\mu \mathrm{m}$ in C. microspora], while C. borreriae produces thicker conidia (up to $15 \mu \mathrm{m}$ ). Curvularia trifolii differs from $C$. austriaca in producing longer conidiophores (up to $400 \mu \mathrm{m}$ ) and more protuberant conidial hila, while $C$. pallescens can be distinguished by its pale to somewhat coloured, almost concolorous conidia. The three strains belonging to C. austriaca were isolated from human clinical specimens, while the other species are associated with plant hosts, air or soil (Manamgoda et al. 2014; Tan et al. 2018; Farr and Rossman 2019).

Curvularia cactivora (Petr.) Y. Marín \& Crous, comb. nov. Fig. 4.

\section{MB832462}

Basionym. Helminthosporium cactivorum Petr., Gartenbauwissenschaft 5: 226 (1931).

Synonyms. Drechslera cactivora (Petr.) M.B. Ellis, Dematiaceous Hyphomycetes (Kew): 432 (1971).

Bipolaris cactivora (Petr.) Alcorn, Mycotaxon 17: 67 (1983).

Reference strain: Republic of Suriname: on Cactaceae, isol. J.H. van Emden, CBS 580.74 (reference strain designated here).

Asexual morph on PDA Hyphae hyaline, branched, septate, thin-walled, 2.5-5.5 $\mu \mathrm{m}$. Conidiophores arising in groups, mononematous, macronematous, rarely semimacronematous, septate, straight or flexuous, geniculate at upper part, cell size decreasing towards apex, irregularly branched, cell walls thicker than those of vegetative hyphae, pale brown to brown, paler towards apex, up to $1000 \mu \mathrm{m}$ long. Conidiogenous cells smooth-walled, terminal or intercalary, proliferating sympodially, pale brown to brown, subcylindrical to slightly swollen, (10)14-50(60) × 4.5-10(20) $\mu \mathrm{m}$. Conidia smoothwalled, straight, rarely curved, ellipsoidal to obclavate, rarely irregular, subhyaline, becoming pale brown to brown when mature, 0-3(5)-distoseptate, (18)26-51 × 6.5-14 $\mu \mathrm{m}$; hila protuberant, darkened, thickened, 2-4 $\mu \mathrm{m}$ wide. Chlamydospores, microconidiation and sexual morph not observed.

Culture characteristics Colonies on PDA covering the surface of the Petri dish in 1 week, olivaceous to dark olivaceous, margin hyaline, powdery to granular, abundantly sporulating; reverse grey olivaceous to olivaceous black, margin hyaline.

Notes Curvularia cactivora was originally described in Helminthosporium (Petrak 1931). Later, it was transferred to Drechslera (Ellis 1971), and then to Bipolaris (Alcorn 1983a). In the most recent revision of the genus Bipolaris, Manamgoda et al. (2014) considered the placement of this species as doubtful since it is morphologically similar to $C$. hawaiiensis. However, they did not include sequence data of this species at the time, and its placement in Curvularia could not be demonstrated. The type specimen of this species could not be located. It was isolated from a member of the Cactaceae in 


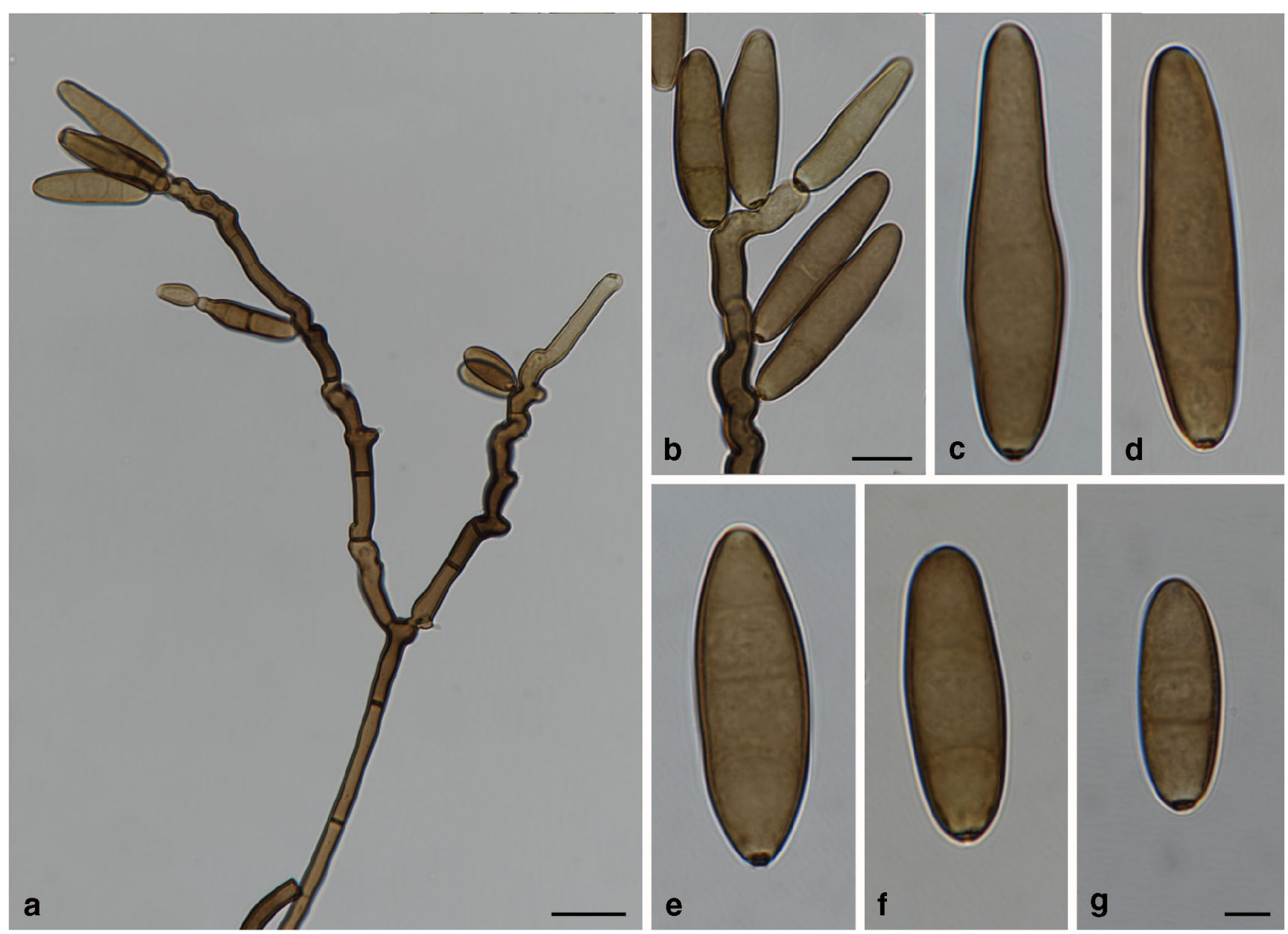

Fig. 4 Curvularia cactivora (CBS 580.74 reference strain). a Conidiophore, conidiogenous cells and conidia; $\mathbf{b}$ conidiogenous cells and conidia; $\mathbf{c}-\mathbf{g}$ conidia. Scale bars a $20 \mu \mathrm{m}$; b $10 \mu \mathrm{m} ; \mathbf{g} 5 \mu \mathrm{m}$, g applies to $\mathbf{c}-\mathbf{g}$

Moravia, Czech Republic (Petrak 1931). In the present study, CBS 580.74 is considered as a reference strain since it was also isolated from a member of the Cactaceae, and its morphology fits with the original description. The only difference found with the original description (Petrak 1931) and the description available in Ellis (1971) is the conidiophore size (up to $1000 \mu \mathrm{m}$ in our study vs $280 \mu \mathrm{m}$ in Petrak 1931 vs $280 \mu \mathrm{m}$ in Ellis 1971). Our phylogenetic study (Fig. 1) places this species in Curvularia. It grouped with other strains identified as C. cactivora, i.e. DB13GEN09, 737, 738 and 739, whose morphology fits with the original description of this species, three of them $(737,738,739)$ causing fruit rot on Hylocereus undatus (Cactaceae) in South Florida (Tarnowski et al. 2010), and the other (DB13GEN09) causing stem rot on Cereus peruvianus var. monstruosus (Cactaceae) in Italy (Garibaldi et al. 2014). In all these strains, the conidiophore size is similar to that mentioned in the original description, being up to $313 \mu \mathrm{m}$ long in the strains from South Florida, and up to
$176 \mu \mathrm{m}$ long in the strain from Italy (Tarnowski et al. 2010; Garibaldi et al. 2014).

Curvularia canadensis Y. Marín \& Crous, sp. nov. Fig. 5. MB830047

Etymology. Named after the country where the material was collected, Canada.

Holotype. Canada: Vancouver, Acadia park (the campus of UBC), from overwintered grass, Sep. 2000, G. Zhang, CBS $\mathrm{H}-24092$.

Ex-type strain. CBS 109239.

Asexual morph on PDA Hyphae hyaline to subhyaline, branched, septate, thin-walled, 1.5-5 $\mu \mathrm{m}$. Conidiophores arising in groups, mononematous, macronematous, septate, flexuous, rarely straight, geniculate at upper part, cell size not decreasing towards apex, frequently 2-3-branched, cell walls thicker than those of vegetative hyphae, pale brown to brown, paler towards apex, not swollen at the base, 65-220 × 3-6 $\mu \mathrm{m}$. Conidiogenous cells smooth-walled, terminal or intercalary, proliferating sympodially, pale brown to brown, subcylindrical 

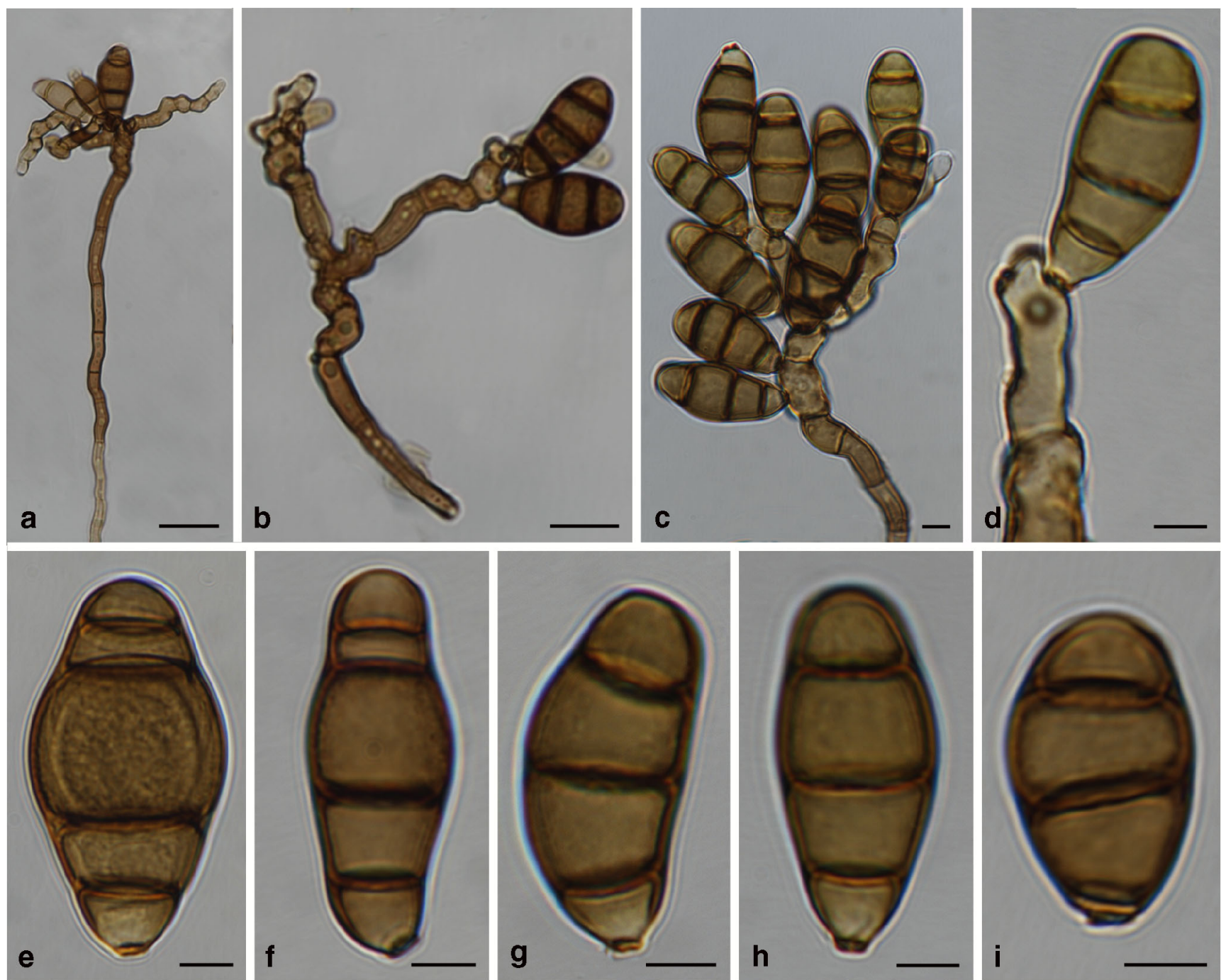

Fig. 5 Curvularia canadensis (CBS 109239 ex-type). a-c Conidiophores, conidiogenous cells and conidia; d conidiogenous cells and conidia; e-i conidia. Scale bars $\mathbf{a}, \mathbf{b}=10 \mu \mathrm{m} ; \mathbf{c}-\mathbf{i}=5 \mu \mathrm{m}$

to swollen, 5.5-16 × 4.5-9 $\mu \mathrm{m}$. Conidia finely verruculose, straight to curved, middle cells disproportionately enlarged, ellipsoidal to broadly ellipsoidal or ovoid, brown, apical cells paler than middle cells being subhyaline to pale brown, (1)3-4distoseptate, 12-36 × 8-16.5(19) $\mu \mathrm{m}$; hila protuberant, darkened, thickened, 1.5-3 $\mu \mathrm{m}$ wide. Chlamydospores, microconidiation and sexual morph not observed.

Culture characteristics Colonies on PDA reaching 58-60 mm diam in 1 week, powdery, greenish black, margin fimbriate; reverse olivaceous black.

Notes Curvularia canadensis formed a clade separate from the other Curvularia spp., with $C$. oryzae-sativae being its closest relative. Both species were found on grass, which is the common host of Curvularia spp., but $C$. canadensis was collected in Canada, while C. oryzae-sativae was reported only in Argentina. Morphologically, C. oryzae-sativae can be easily distinguished by its mostly straight conidia with the middle cells not as enlarged as in $C$. canadensis, and with more distosepta [3-8 (mostly 6-7) in C. oryzae-sativae vs (1)3-4 in C. canadensis].

Curvularia crassiseptata Meng Zhang \& T.Y. Zhang, Mycosystema 23: 177 (2004) (as 'crassiseptum'). Fig. 6.

Replaced synonym. Exserohilum inaequale Sivan., Trans. Brit. Mycol. Soc. 83: 325 (1984), non Curvularia inaequalis (Shear) Boedijn (1907).

Holotype. Nigeria: from plant material, D.B. Olufolagi, IMI 280438.

Ex-type strain. CBS $503.90=$ IMI 280438.

Asexual morph on PDA Hyphae subhyaline to pale brown, branched, septate, thin to thick-walled, (1.5)2-4(5) $\mu \mathrm{m}$. Conidiophores arising single or in small groups, mononematous, semi- to macronematous, septate, straight or flexuous, sometimes geniculate at upper part, cell size not decreasing towards apex, unbranched, cell walls thicker than those of vegetative hyphae, pale brown to brown, paler 
towards apex, up to $500 \mu \mathrm{m}$. Conidiogenous cells smoothwalled to slightly verruculose, terminal or intercalary, sometimes proliferating sympodially, pale brown to brown, subcylindrical to slightly swollen, 7-26(28.5) $\times 5-8 \mu \mathrm{m}$. Conidia smooth-walled to finely verruculose, straight or curved, ellipsoidal, broadly ellipsoidal or ovoid, middle cells enlarged, pale brown to brown, apical and basal cells usually paler, (2)3-5(6)-distoseptate, (25)33.5-50(60) × (14)16$23.5 \mu \mathrm{m}$; hila protuberant, rarely darkened, thickened, $2-$ 3.5(4) $\mu \mathrm{m}$ wide, 1.5-3 $\mu \mathrm{m}$ long. Chlamydospores, microconidiation and sexual morph not observed.

Culture characteristics Colonies on PDA covering the surface of the Petri dish in 1 week, smoke grey to grey olivaceous, abundant aerial mycelium giving the colony a cottony appearance; reverse dark slate blue.
Notes This species was initially described as Exserohilum inaequale, due to the production of conidia with protuberant hila similar to those found in this genus (Sivanesan 1984). Subsequently, it was transferred to Curvularia changing the epithet to $C$. crassiseptata since inaequale was pre-occupied by another species (Zhang et al. 2004). Recently, the position of this species in Curvularia was confirmed by HernándezRestrepo et al. (2018). In the present study, we provide a morphological description and illustrations of the type material.

Curvularia crassiseptata is located in a clade together with C. cymbopogonis and C. heteropogonicola (Fig. 1), all of which produce conidia with protuberant hila (Sivanesan 1984; Manamgoda et al. 2014). Curvularia crassiseptata
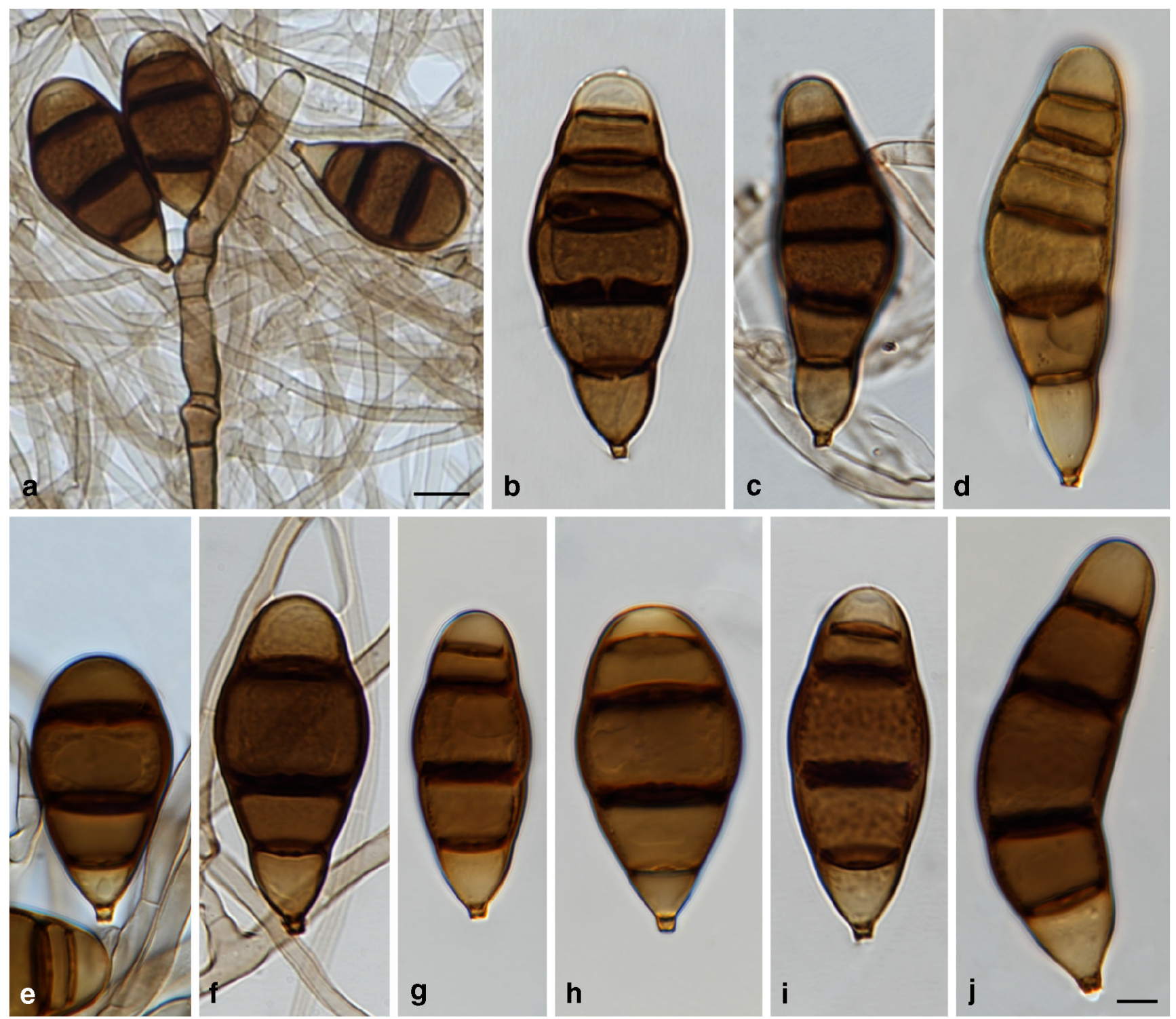

Fig. 6 Curvularia crassiseptata (CBS 503.90 ex-type). a Conidiogenous cells and conidia; b-j conidia. Scale bars a $10 \mu \mathrm{m} ; \mathbf{j} 5 \mu \mathrm{m}, \mathbf{j}$ applies to b-j 
differs from $C$. heteropogonicola by the size and septation of its conidia [(25)33.5-50(60) $\times(14) 16-23.5 \mu \mathrm{m}$ and (2)35(6)-distoseptate in $C$. crassiseptata vs $41-80 \times 16-21 \mu \mathrm{m}$ and 3-10-distoseptate in C. heteropogonicola (Sivanesan 1984)]. It can be distinguished from C. cymbopogonis by having (2)3-5(6)-distoseptate conidia, while those of C. cymbopogonis are 4-distoseptate (Manamgoda et al. 2014).

\section{Curvularia ellisii Y. Marín \& Crous, sp. nov. Fig. 7. \\ MB830048}

Synonyms: Curvularia ellisii S.I. Ahmad \& Quraishi [as 'ellisi'], Pakistan J. Sci. Industr. Res. 3: 177 (1960), nom. inval., Art. 39.1 (Melbourne).

Drechslera ellisii Danquah, Trans. Brit. Mycol. Soc. 64: 545 (1975).

Bipolaris ellisii (Danquah) Alcorn, Trans. Brit. Mycol. Soc. 81: 174 (1983).

Cochliobolus ellisii Alcorn, Trans. Brit. Mycol. Soc. 81: 172 (1983).

Holotype. Pakistan: Karachi, isolated from air, 1956, M.S. Quraishi, CBS 193.62 (specimen preserved as metabolically inactive strain).

Ex-type strain. CBS 193.62= ATCC $14848=$ IMI $75862=$ QM 8355 = DAOM 155097.

Additional material examined. Australia: on Dactyloctenium aegyptium (Poaceae), 24 Dec. 1981, J.L. Alcorn, CBS 127083 = BRIP 13509a (derived from sexual morph, BRIP 13515).

Asexual morph on PDA Hyphae subhyaline to pale brown, branched, septate, 2-4 $\mathrm{m}$. Conidiophores arising in groups, mononematous, semi- to macronematous, septate, straight or flexuous, geniculate at upper part, cell size not decreasing towards apex, branched, cell walls thicker than those of vegetative hyphae, pale brown to brown, paler towards apex, not swollen at the base, 45-700 $\times(2.5) 4-7.5 \mu \mathrm{m}$. Conidiogenous cells verruculose, terminal or intercalary, proliferating sympodially, pale brown to brown, subcylindrical to swollen, 7.5-16.5 × 5-7.5(9) $\mu \mathrm{m}$. Conidia verruculose, straight or curved, ovoid, pale brown to brown, paler towards hilum, (2)3-4(5)-distoseptate, (11.5)14-23.5(26) × (8)9.5-13(14.5) $\mu \mathrm{m}$; hila flat to slightly protuberant, darkened, thickened, 2 $4 \mu \mathrm{m}$ wide. Chlamydospores, microconidiation and sexual morph not observed.

Culture characteristics Colonies on PDA reaching 57-61 mm diam in 1 week, fuscous olivaceous, fasciculate, margin fimbriate; reverse olivaceous black.

Notes Curvularia ellisii (Pakistan, isolated from air, ex-type CBS 193.62) was introduced by Ahmad and Quraishi (1960), but due to the lack of a Latin description, the name was invalid. Danquah (1975) again used this epithet for a species he described in Drechslera (Ghana, from Capsicum sp.), as D. ellisii. Alcorn (1983b) described Cochliobolus ellisii (Australia, on the leaves of Zea mays, BRIP 13633), which he considered the sexual morph of D. ellisii (as Bipolaris ellisii comb. nov.). Based on DNA sequence data, Manamgoda et al. (2012) used the name Curvularia ellisii, which is, however, invalid. Here we validate the original name, $C$. ellisii, based on the ex-type culture deposited by M.S. Quraishi, CBS 193.62.
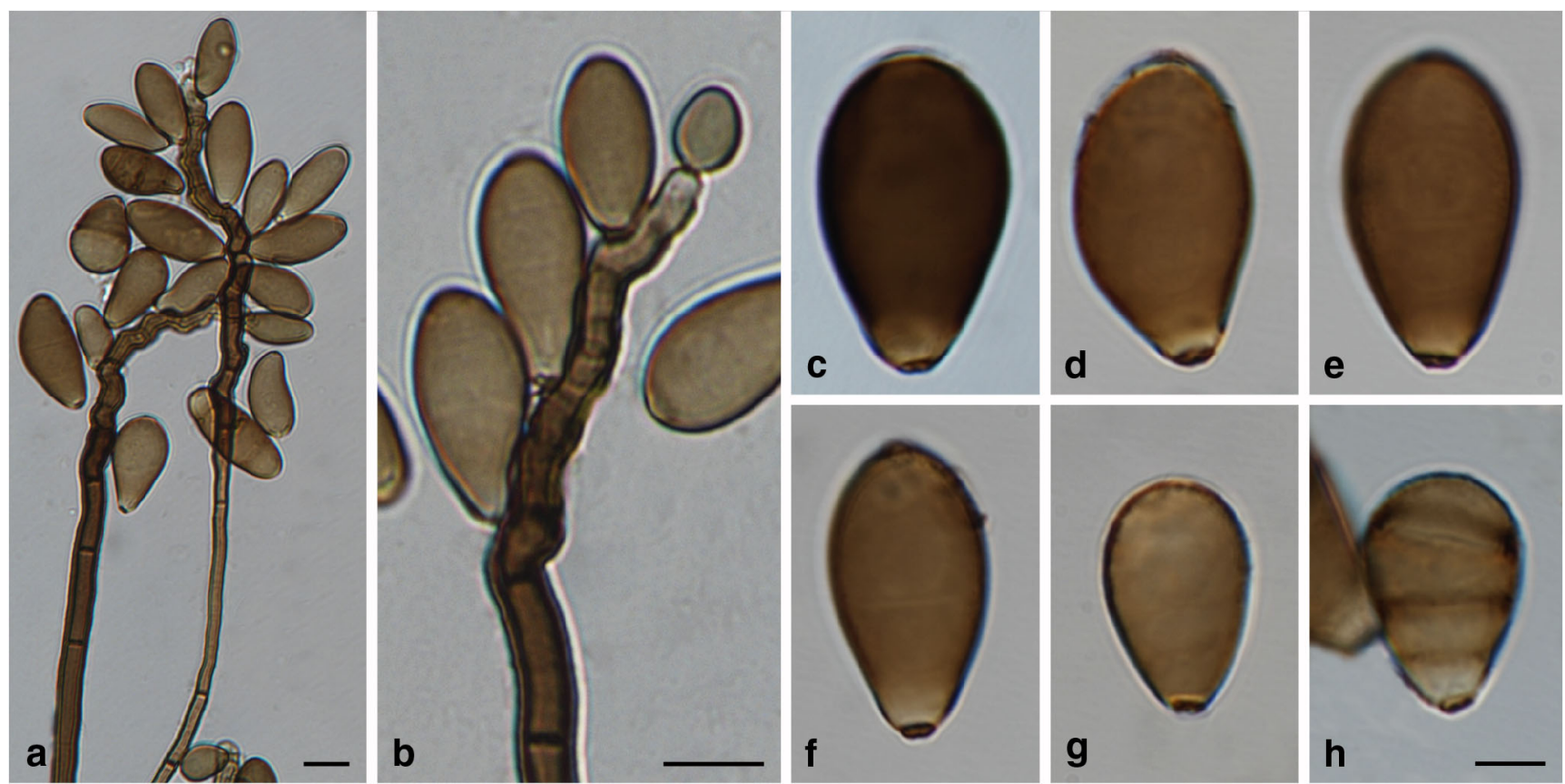

Fig. 7 Curvularia ellisii (CBS 127083). a Conidiophores, conidiogenous cells and conidia; $\mathbf{b}$ conidiogenous cells and conidia; $\mathbf{c}-\mathbf{h}$ conidia. Scale bars $\mathbf{a}$, b $10 \mu \mathrm{m} ; \mathbf{h} 5 \mu \mathrm{m}$, $\mathbf{h}$ applies to $\mathbf{c}-\mathbf{h}$ 
Curvularia ellisii is related to C. neergaardii and C. pseudoellisii, another new species proposed in the present study (Fig. 1). See notes of the latter species for morphological differences among these taxa.

Curvularia neergaardii (Danquah) Y.P. Tan \& R.G. Shivas, Australas. Pl. Pathol. 43: 600 (2014). Fig. 8.

Basionym. Drechslera neergaardii Danquah, Trans. Brit. Mycol. Soc. 64: 545 (1975).

Synonyms. Bipolaris neergaardii (Danquah) Alcorn, Mycotaxon 17: 68 (1983).

Cochliobolus neergaardii Alcorn, Mycotaxon 39: 385 (1990).

Holotype. Ghana: from seeds of Oryza sativa (Poaceae), 1973, O.A. Danquah, IMI 174949.

Ex-isotype strain. BRIP 12919.

Additional material examined. Australia: Queensland, May 1985, J.L. Alcorn, CBS 276.91 = Alcorn 8509-2; CBS 277.91 = Alcorn 8509-3.

Asexual morph on PDA Hyphae hyaline to pale brown, branched, septate, thin-walled, 2-5.5 $\mu \mathrm{m}$. Conidiophores arising in groups, septate, mononematous, macronematous, straight or flexuous, geniculate at upper part, verruculose, cell size not decreasing towards apex, sometimes branched, cell walls thicker than those of vegetative hyphae, pale brown to brown, paler towards apex, rarely slightly swollen at the base, 50-275(370) $\times(1.8) 2.5-5 \mu \mathrm{m}$. Conidiogenous cells verruculose, terminal or intercalary, proliferating sympodially, pale brown to brown, subcylindrical to swollen, 5.5$17.5(19.5) \times 4.5-7 \mu \mathrm{m}$. Conidia verruculose, subglobose to broadly ellipsoidal, pale brown to brown, paler at both apices, 1-3-distoseptate, 14.5-24 ×9.5-16 $\mu \mathrm{m}$; hila sometimes inconspicuous, flat to slightly protuberant, darkened, thickened, 1-3 $\mu \mathrm{m}$ wide. Chlamydospores, microconidiation and sexual morph not observed.

Culture characteristics Colonies on PDA reaching 53-59 mm diam in 1 week, olivaceous black with white to olivaceous grey zones, with sparse aerial mycelium, margin fimbriate; reverse olivaceous black to dark slate blue.

Notes Curvularia neergaardii was originally described in Drechslera by Danquah (1975), and subsequently transferred to Bipolaris (Alcorn 1983a). Finally, Tan et al. (2014) placed this taxon in Curvularia based on sequence data obtained from the ex-type strain. Alcorn (1990) described the sexual morph as Cochliobolus neergaardii, which is now a synonym of $C$. neergaardii based on the new fungal nomenclature (Tan
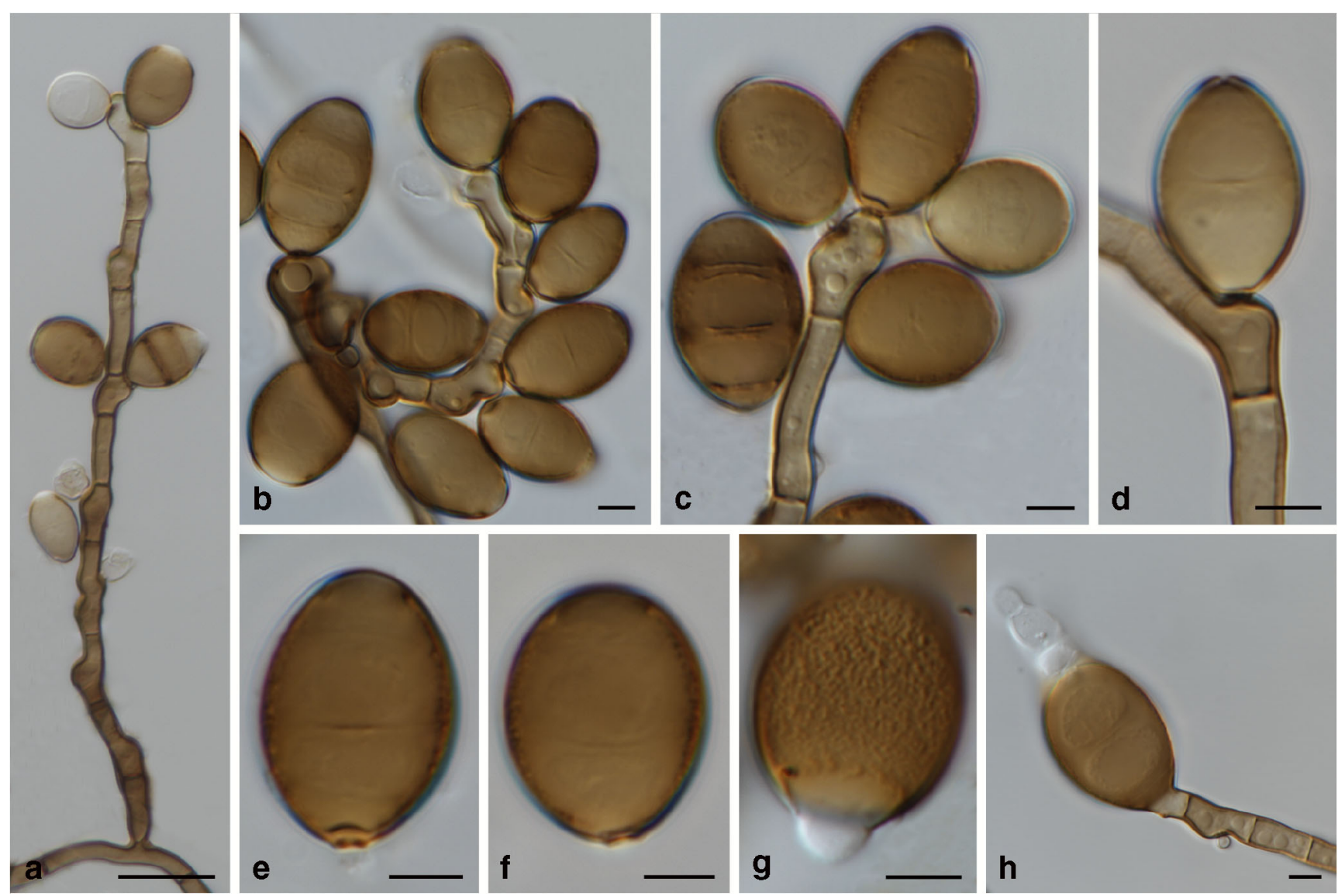

Fig. 8 Curvularia neergaardii (CBS 277.91). a Conidiophore, conidiogenous cells and conidia; b-d conidiogenous cells and conidia; $\mathbf{e}-\mathbf{g}$ conidia; $\mathbf{h}$ germinating conidium. Scale bars a $20 \mu \mathrm{m}$, all others $5 \mu \mathrm{m}$. Pictures $\mathbf{a}$ and $\mathbf{h}$ taken from Marin-Felix et al. (2017a) 
et al. 2014). In the present study, we provide a description and illustrations of the asexual morph of this species (Fig. 8).

Curvularia neergaardii is related to the new species C. pseudoellisii and C. ellisii, both proposed in the present study (Fig. 1). For a morphological comparison, see notes of C. pseudoellisii.

Curvularia oryzae Bugnic., Rev. Gén. Bot. 57: 69 (1950). Fig. 9.

Ex-isotype strain. Vietnam: from Oryza sativa seed (Poaceae), 1949, coll. J. Nicot, isol. F. Bugnicourt, CBS 169.53.

Asexual morph on PDA Hyphae hyaline to pale brown, branched, septate, thin-walled, 1-4 $\mu \mathrm{m}$. Conidiophores arising in groups, mononematous, semi- to macronematous, septate, straight or flexuous, sometimes geniculate at upper part, rarely branched, cell walls thicker than those of vegetative hyphae, pale brown to brown, paler towards apex, 40-400 $\times$ 3-8 $\mu \mathrm{m}$. Conidiogenous cells smooth-walled to finely verruculose, terminal or intercalary, sometimes proliferating sympodially, pale brown to brown, subcylindrical to slightly swollen, 6.5-20(29) $\times 5-8.5 \mu \mathrm{m}$. Conidia smooth-walled to finely verruculose, straight to slightly curved, rarely curved, middle cells enlarged, ellipsoidal to broadly ellipsoidal or obovoid, pale brown to brown, apical cells paler, (2)3-distoseptate, 20 $37.5 \times 11-21.5 \mu \mathrm{m}$; hila flat to slightly protuberant, darkened, thickened, 2-4.7 $\mu \mathrm{m}$ wide. Chlamydospores, microconidiation and sexual morph not observed.

Culture characteristics Colonies on PDA covering the surface of the Petri dish in 1 week, saffron to apricot, abundant aerial mycelium giving the colony a cottony appearance; reverse saffron to apricot or umber.

Notes This species is related to $C$. reesii and $C$. tuberculata (Fig. 1). Curvularia oryzae and C. tuberculata are mainly found in Asia (Farr and Rossman 2019) while C. reesii occurs in Australia (Tan et al. 2018). Curvularia tuberculata can be distinguished by having verrucose or rough, longer (up to $51 \mu \mathrm{m}$ long) conidia. Curvularia reesii produces shorter conidiophores (up to $200 \mu \mathrm{m}$ long) and conidia (up to $14 \mu \mathrm{m}$ long) than C. oryzae (up to 400 and $21.5 \mu \mathrm{m}$ long, respectively). A morphological description and illustrations are provided of the ex-type strain (Fig. 9).
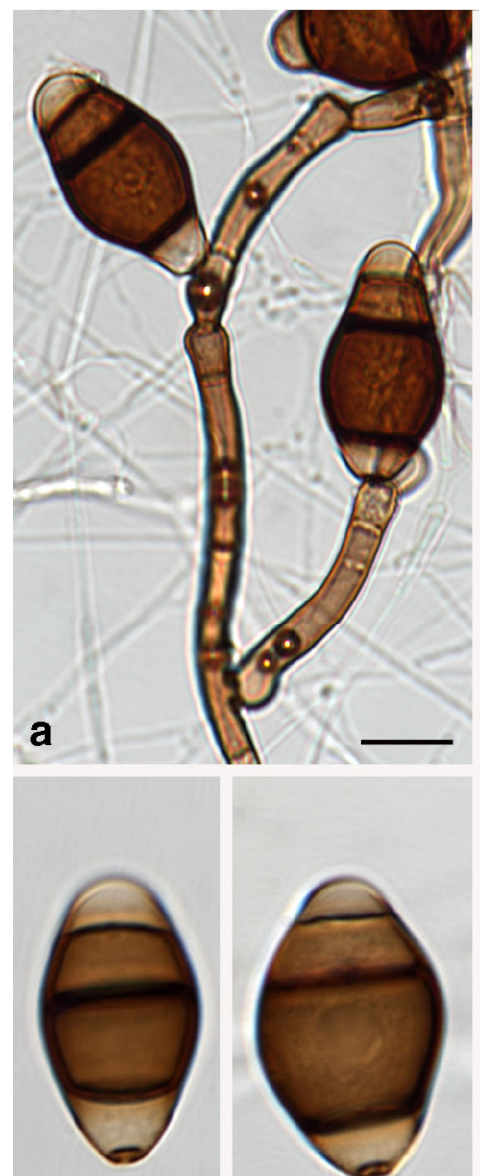

e

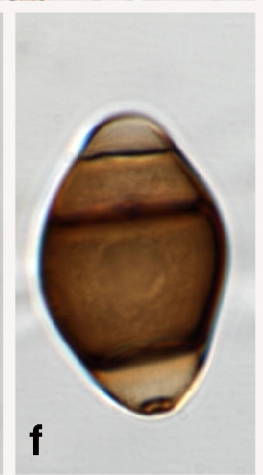

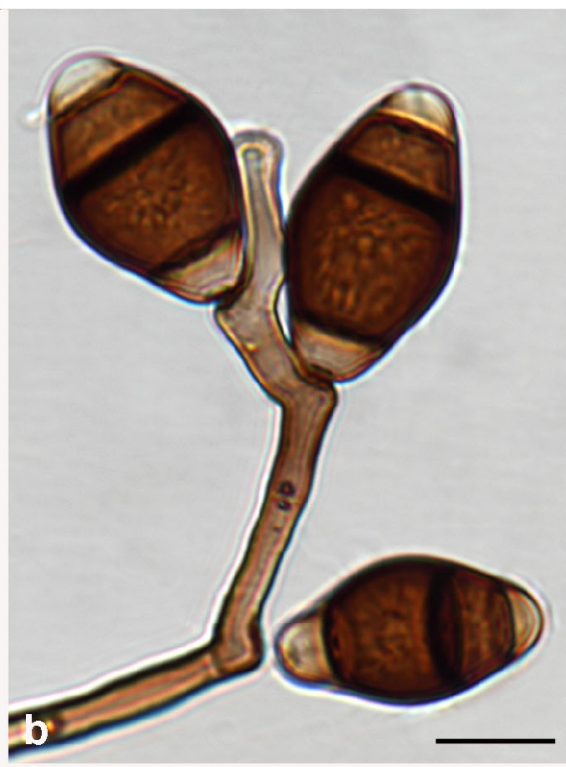
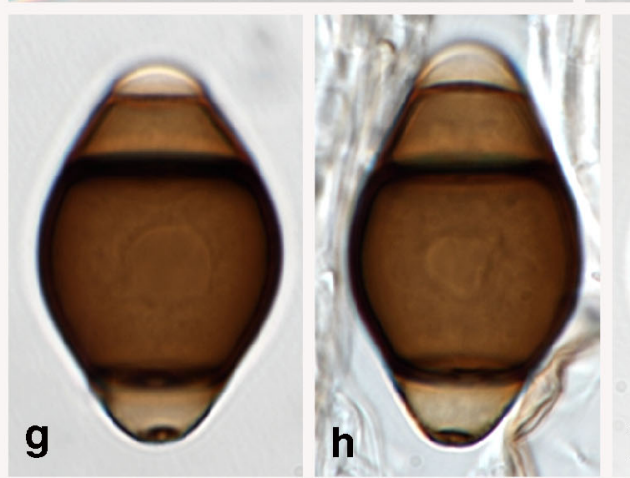
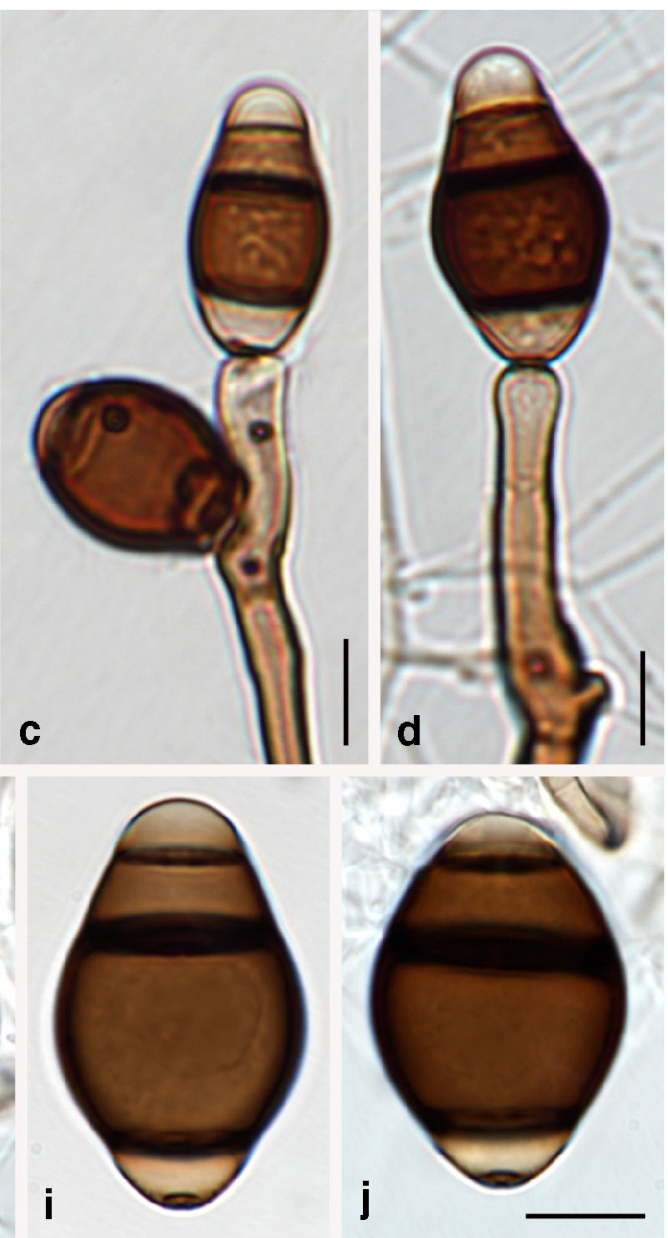

Fig. 9 Curvularia oryzae (CBS 169.53 ex-isotype). Conidiogenous cells and conidia; a-d e-j conidia. Scale bars a, b $15 \mu \mathrm{m} ; \mathbf{c}, \mathbf{d}, \mathbf{j} 10 \mu \mathrm{m}, \mathbf{j}$ applies to e-j 
Curvularia oryzae-sativae Sivan., Mycol. Pap. 158: 140 (1987). Fig. 10.

Holotype. Argentina: Buenos Aires, from Oryza sativa seed (Poaceae), 8 Oct. 1984, IMI 289758.

Epitype designated here. Argentina: from Oryza sativa seed (Poaceae), 28 Jul. 1986, M.N. Sisterna, CBS H-24093.

Ex-epitype strain. CBS 127725 = BRIP 15350a.

Asexual morph on PDA Hyphae hyaline to pale brown, branched, septate, thick-walled, 1.5-3.5 $\mu \mathrm{m}$. Conidiophores arising in groups, mononematous, semi- to macronematous, septate, straight or flexuous, geniculate at upper part, branched, cell walls thicker than those of vegetative hyphae, pale brown to brown, paler towards apex, not swollen at the base, 80-440 ×(2.5)3-6 $\mu \mathrm{m}$. Conidiogenous cells smoothwalled to verruculose, terminal or intercalary, proliferating sympodially, pale brown to brown, subcylindrical to swollen, 7.5-16 × 4.5-8.5 $\mu \mathrm{m}$. Conidia smooth-walled to finely verruculose, straight or curved, usually middle cells enlarged, ellipsoidal to ovoid, brown, basal cells and sometimes apical cells paler, 3-7(8)-distoseptate, 20.5$50(61) \times(8.5) 10-12.5 \mu \mathrm{m}$; hila protuberant, darkened, thickened, (2.5)3-4 $\mu \mathrm{m}$ wide. Chlamydospores, microconidiation and sexual morph not observed.

Culture characteristics Colonies on PDA reaching 50-60 mm diam in 1 week, grey olivaceous, sparse aerial mycelium, margin lobate; reverse dark slate blue.

Notes As no living culture was associated with the original material, we designate an epitype with an ex-epitype culture to phylogenetically fix the application of this name. The epitype was found on the same host in the same location as the holotype. A description and illustrations are provided in the present study (Fig. 10). Hitherto, this species has neither been reported from another host nor from another region.

Curvularia oryzae-sativae is related to C. canadensis (Fig. 1 ), but this can be easily distinguished based on morphology (for morphological differences, see notes under $C$. canadensis).

Curvularia patereae (M.R. Carranza) Y. Marín, Hern.Restr. \& Crous, comb. nov.

\section{MB830049}

Basionym. Drechslera patereae M.R. Carranza, Revista Fac. Agron. Univ. Nac. La Plata 59: 66 (1983).

Synonym. Bipolaris patereae (M.R. Carranza) B.A. Khasanov, Opredelitel' Gribov-Vozbuditele 'Gel'mintosporiozov' Rasteniǔ iz Rodov Bipolaris, Drechslera i Exserohilum (Tashkent): 78 (1992).

Ex-type strain. Argentina: on Triticum durum seed (Poaceae), M.R. Carranza, CBS 198.87.

Description adapted from Carranza (1983) Conidiophores arising single or in groups, mononematous, macronematous, septate, straight, sometimes geniculate at upper part, unbranched, 37.5-130 × 3.5-7.5 $\mu \mathrm{m}$. Conidiogenous cells terminal or intercalary, proliferating sympodially, subcylindrical to swollen. Conidia straight or curved, ellipsoidal to ovoid, sometimes middle cells slightly enlarged, 2-6distoseptate, 16.5-30 × 7.5-9 $\mu \mathrm{m}$; hila protuberant, darkened, thickened. Chlamydospores, microconidiation and sexual morph not observed.

Notes This species was introduced by Carranza (1983) as Drechslera patereae, a fungus causing a seedborne disease in Triticum durum. Subsequently, it was transferred to Bipolaris by Khasanov (1992). In our phylogenetic study, the ex-type strain clustered in Curvularia (Fig. 1). Therefore, the new combination $C$. patereae is herewith proposed.

Curvularia patereae is related to $C$. mebaldsii, C. tsudae and $C$. penniseti (Fig. 1). These species all produce 3distoseptate conidia, except for $C$. patereae, which is characterised by 2-6-distoseptate conidia. Curvularia penniseti can be easily distinguished by its larger conidia (29-42 $\mu \mathrm{m}$ vs up to $30 \mu \mathrm{m}$ in the other three species) with an enlarged middle cell, which is not or slightly enlarged in the other species. The four species of this clade are mainly reported on members of the Poaceae (Farr and Rossman 2019).

Curvularia protuberata R.R. Nelson \& Hodges, Mycologia 57: 823 (1965). Fig. 11.

Holotype. Scotland: Edinburgh, from Deschampsia flexuosa leaf (Poaceae), 24 Aug. 1964, R.R. Nelson, BPI 442848.

Ex-type strain. CBS $376.65=$ ATCC $16397=\mathrm{IMI}$ 115840 .

Asexual morph on PDA Hyphae hyaline to pale brown, branched, septate, 1.5-5.5 $\mu \mathrm{m}$. Conidiophores arising single or in groups, mononematous, semi- to macronematous, septate, straight or flexuous, geniculate at upper part, sometimes branched, cell walls thicker than those of vegetative hyphae, pale brown, rarely paler towards apex, cell size not decreasing towards apex, rarely swollen at the base, 55$300 \times 2.5-5 \mu \mathrm{m}$. Conidiogenous cells smooth-walled to slightly verruculose, terminal or intercalary, proliferating sympodially, pale brown, subcylindrical to swollen, 4.5-14 $\times$ 4-7(8.5) $\mu \mathrm{m}$. Conidia smooth-walled, straight or curved, ellipsoidal to ovoid, middle cells enlarged, pale brown to brown, apical and basal cells paler, 3(4)-distoseptate, 16.5-27.5 $\times 8$ $12.5 \mu \mathrm{m}$; hila protuberant, darkened, thickened, 2-3(4) $\mu \mathrm{m}$ wide. Chlamydospores, microconidiation and sexual morph not observed.

Culture characteristics Colonies on PDA covering the dish in 1 week, smoke grey to olivaceous black, abundant aerial mycelium giving the colony a cottony appearance, margin lobate; reverse olivaceous black.

Notes Curvularia protuberata was introduced for a specimen with protruding hila (Nelson 1965). In the present study, a morphological description and illustrations are 


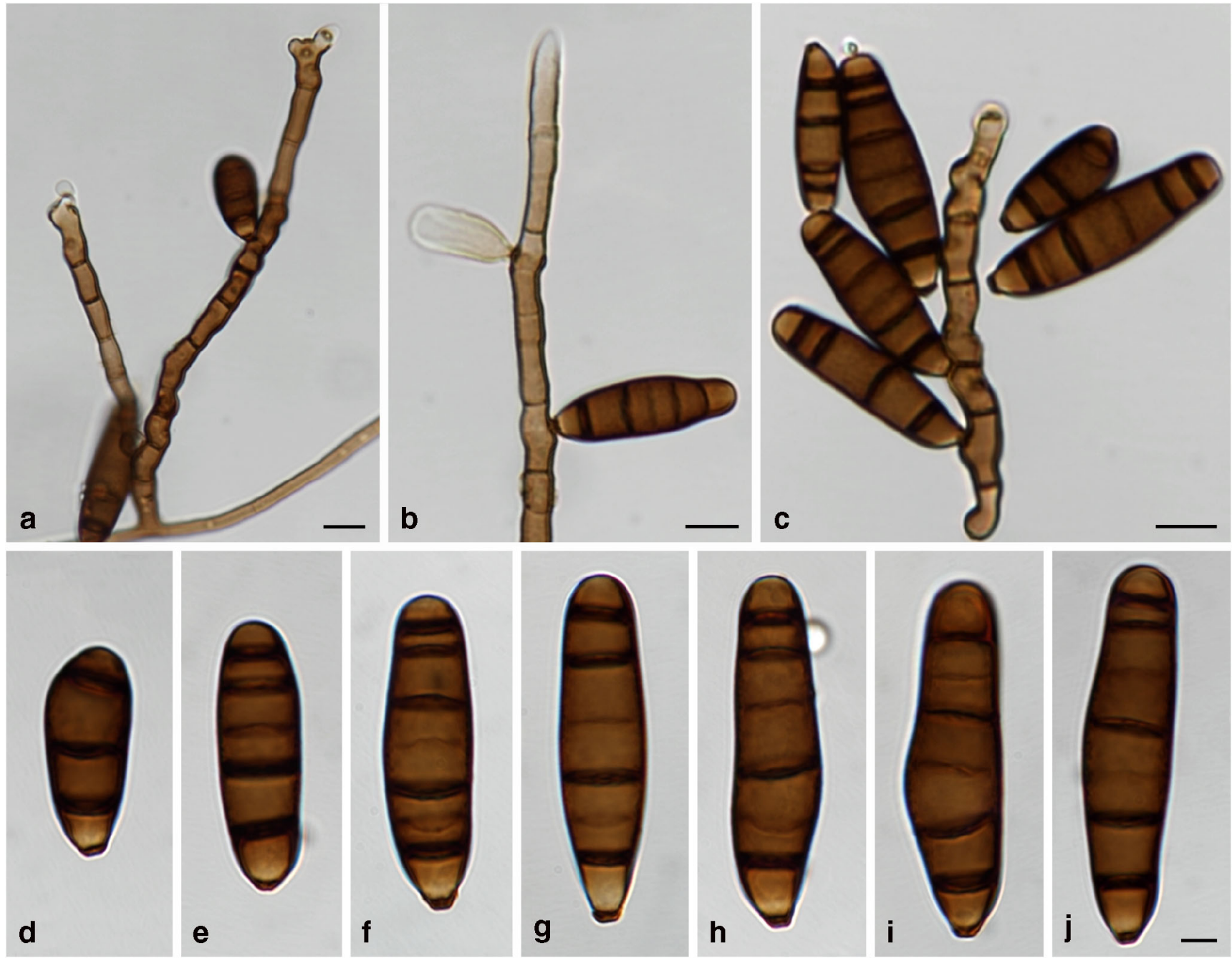

Fig. 10 Curvularia oryzae-sativae (CBS 127725 ex-epitype). a Conidiophore, conidiogenous cells and conidia; b, c conidiogenous cells and conidia; d$\mathbf{j}$ conidia. Scale bars $\mathbf{a}-\mathbf{c} 10 \mu \mathrm{m} ; \mathbf{j} 5 \mu \mathrm{m}, \mathbf{j}$ applies to $\mathbf{d}-\mathbf{j}$

provided for the ex-type (Fig. 11). The species is similar and phylogenetically related to C. pseudoprotuberata, a new species introduced below. For a morphological comparison, see notes under $C$. pseudoprotuberata.

Curvularia protuberata has been reported on a wide host range including the families Fabaceae (Aeschynomene falcata, Glycine max), Juncaceae (Juncus roemerianus) and Poaceae (Aristida oligantha, Avena sativa, Deschampsia spp., Eragrostis spp., Panicum texanum, Paspalum dilatatum, Phleum spp., Sorghum sp., Sporobolus vaginiflorus, Tridens flavus, Tripsacum dactyloides, Triticum durum, Zea mays), from Africa, America and Europe (Farr and Rossman 2019).

Curvularia pseudobrachyspora Y. Marín, Cheew. \& Crous, Mycosphere 8: 1569 (2017). Fig. 12.

Holotype. Thailand: Chiang Mai, Jom Thong, on Eleusine indica (Poaceae), 23 May 2010, R. Cheewangkoon, CBS H-23195.

Ex-type strain. CPC 28808.
Additional material examined. China: Hainan Province, Wanning, on Areca catechu leaf (Arecaceae), Jul. 2017, HNWN001. Denmark: on Pennisetum sp. seed (Poaceae), 16 Apr. 1970, S.B. Mathur, CBS $533.70=$ IMI 148192. Thailand: on Oryza sativa (Poaceae), D.S. Manamgoda, MFLUCC 100739. Unknown location, substrate, date and collector, CBS 207.59 = ATCC 13633 = NRRL 2434. USA: on Trisetum sp. (Poaceae), R.R. Nelson, CBS 336.64 = MUCL 38848; ibid., on Agropyron repens (Poaceae), CBS 337.69 = MUCL 38849; ibid., on Pennisetum glaucum (Poaceae), CBS 339.69.

Asexual morph on PDA Hyphae subhyaline to pale brown, branched, septate, thin-walled, (1)1.5-5 $\mu \mathrm{m}$. Conidiophores arising single or in groups, mononematous, semi- to macronematous, septate, straight or flexuous, geniculate at upper part, sometimes swollen at the base, cell size rarely decreasing towards apex, sometimes branched, cell walls thicker than those of vegetative hyphae, pale brown to brown, sometimes paler towards apex, 30 $420 \times(2.5) 3-6(7) \mu \mathrm{m}$. Conidiogenous cells smooth-walled to verruculose, terminal or intercalary, proliferating sympodially, 

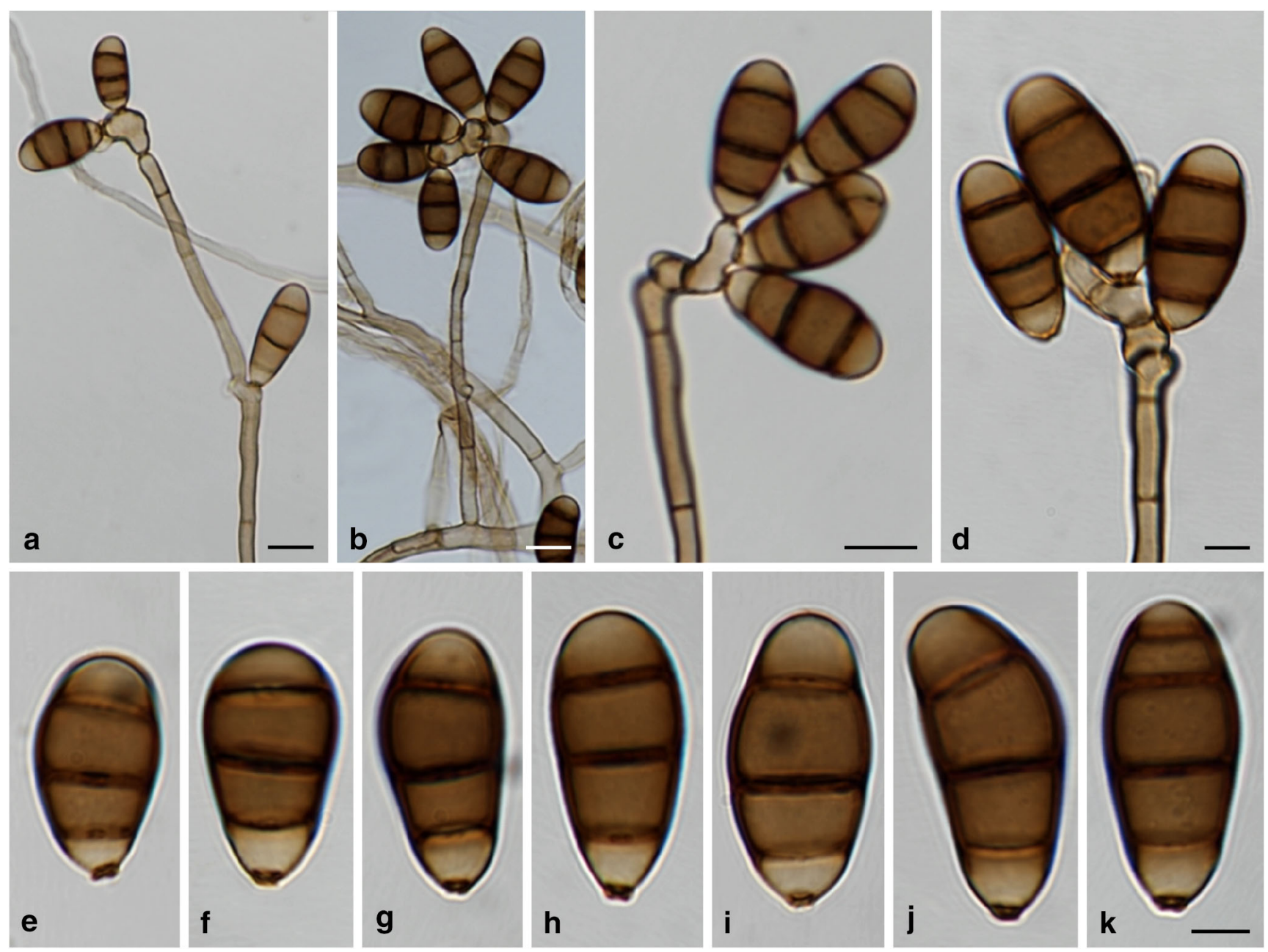

Fig. 11 Curvularia protuberata (CBS 376.65 ex-isotype). a, b Conidiophores, conidiogenous cells and conidia; $\mathbf{c}$, $\mathbf{d}$ conidiogenous cells and conidia; $\mathbf{e}-$ $\mathbf{k}$ conidia. Scale bars $\mathbf{a}-\mathbf{d} 10 \mu \mathrm{m} ; \mathbf{k} 5 \mu \mathrm{m}, \mathbf{k}$ applies to $\mathbf{e}-\mathbf{k}$

pale brown to brown, subcylindrical to swollen, (5)7-27 $\times 4$ 15.5(18) $\mu \mathrm{m}$. Conidia smooth-walled to verruculose, straight or curved, ellipsoidal to ovoid, middle cells enlarged, pale brown to brown, apical cell paler, basal cells sometimes paler, (1)2-3distoseptate, 13-27(28.5) $\times 6-14 \mu \mathrm{m}$; hila inconspicuous to slightly conspicuous, flat to slightly protruding, darkened, slightly thickened, 1.5-3(4) $\mu \mathrm{m}$ wide. Chlamydospores, microconidiation and sexual morph not observed.

Culture characteristics Colonies on PDA reaching 64-90 mm diam in 1 week, smoke grey to grey olivaceous, or with zones of pale mouse grey, and alternate zones grey olivaceous to olivaceous, with sparse aerial mycelium, margin fimbriate; reverse brown to dark brown, with margin pale yellow, or dark olivaceous with margin hyaline.

Notes Curvularia pseudobrachyspora, recently introduced in Marin-Felix et al. (2017b), causes leaf spots on Eleusine indica in Thailand. In our phylogenetic study, seven additional strains, collected in China, Denmark, the USA and Thailand, clustered in the same clade representing C. pseudobrachyspora (Fig. 1).
These strains were isolated from different hosts, i.e. Agropyron repens, Areca catechu, Oryza sativa, Pennisetum glaucum, Pennisetum sp. and Trisetum sp., all of them, exceptAreca catechu, belong to the Poaceae, as well as Eleusine indica, which is the host of the ex-type strain. The strain isolated from Areca catechu (Arecaceae) causes leaf spots. Although this disease has rarely been observed in China to date, it causes serious symptoms in arecapalm (Wang et al. 2019). Apart from the reports on new hosts and distribution, the description of C. pseudobrachyspora is emended here to incorporate the morphology observed in the strain CBS 533.70. Basically, the main difference was in the size of the conidiophores, being $110-420 \times(2.5) 3.5-6(7) \mu \mathrm{m}$ in the ex-type strain, while these measure 30-100(178) $\times 3-5(5.5) \mu \mathrm{m}$ in CBS 533.70.

Curvularia pseudobrachyspora is related to C. brachyspora (Fig. 1). However, C. pseudobrachyspora is easily distinguishable by producing shorter conidiophores (up to $420 \mu \mathrm{m}$ long in C. pseudobrachyspora vs up to $700 \mu \mathrm{m}$ in C. brachyspora; Sivanesan 1987). 

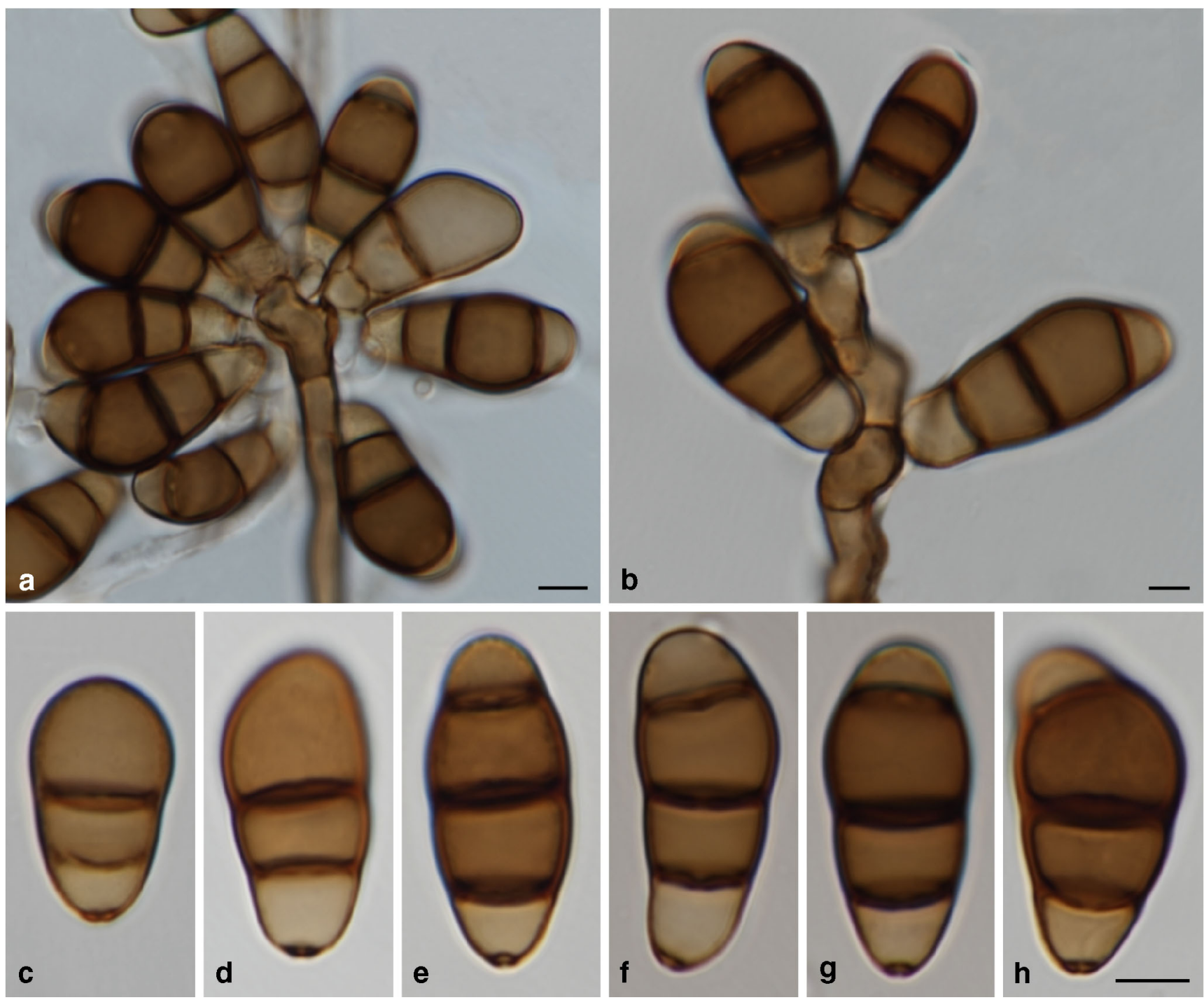

Fig. 12 Curvularia pseudobrachyspora (CBS 533.70). a, b Conidiogenous cells and conidia; $\mathbf{c}-\mathbf{h}$ conidia. Scale bars $5 \mu \mathrm{m}, \mathbf{h}$ applies to $\mathbf{c}-\mathbf{h}$

Curvularia pseudoclavata Y. Marín \& Crous, sp. nov. Fig. 13.

\section{MB830051}

Etymology. Name refers to the similarity with Curvularia clavata.

Holotype. Denmark: Copenhagen, on Oryza sativa seeds (Poaceae), Apr. 1970, S.B. Mathur, preserved in a metabolically inactive state, CBS 539.70 .

Ex-type strain. CBS 539.70 = ATCC $34596=$ IMI 148186. Asexual morph on PDA Hyphae subhyaline to pale brown, branched, septate, thick-walled, 1.5-3.5 $\mu \mathrm{m}$. Conidiophores arising single or in groups, mononematous, semi- to macronematous, septate, straight or flexuous, sometimes geniculate at upper part, branched, cell walls thicker than those of vegetative hyphae, pale brown to brown, usually paler towards apex, not swollen at the base, 34-102.5(137) $\times 2.5-$ $5.5 \mu \mathrm{m}$. Conidiogenous cells smooth-walled, terminal or intercalary, proliferating sympodially, pale brown to brown, subcylindrical to swollen, 5.5-12(17) $\times 4-6 \mu \mathrm{m}$. Conidia verruculose, straight or curved, ovoid to clavate, middle cells disproportionately enlarged, pale brown to brown, apical cells and sometimes basal cells paler, (2)3(4)-distoseptate,

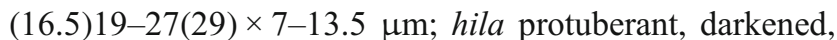
thickened, 2-3 $\mu \mathrm{m}$ wide. Chlamydospores, microconidiation and sexual morph not observed.

Culture characteristics Colonies on PDA reaching 52-57 mm diam in 1 week, saffron to luteous, abundant aerial mycelium giving the colony a cottony appearance, margin luteous to umber and fimbriate; reverse pale luteous to luteous.

Notes In our phylogenetic study, this species was located on an independent branch. The most related species are C. palmicola and C. petersonii. All of them produce mostly 3-distoseptate conidia; however, these differ in size [23.9-34.7 $\times 9.3-15.7 \mu \mathrm{m}$ in C. palmicola vs $(15) 17$ $19(21) \times(5) 5.5-6(7) \mu \mathrm{m}$ in C. petersonii vs $(16.5) 19$ $27(29) \times 7-13.5 \mu \mathrm{m}$ in $C$. pseudoclavata]. Moreover, these 
species have been found on different hosts, i.e. C. palmicola on Acoelorrhaphe wrightii, C. petersonii on Dactyloctenium aegyptium and C. pseudoclavata on Oryza sativa (Hyde et al. 2017; Tan et al. 2018).

Curvularia pseudoclavata is similar to $C$. clavata, both species producing ovoid to clavate, mostly 3 -distoseptate conidia. The size of their asexual structures is also similar. The only difference observed is in the ornamentation of their conidia, being smooth-walled in C. clavata (Sivanesan 1987) and verruculose in C. pseudoclavata. However, both species are phylogenetically distant. Curvularia pseudoclavata was found in Denmark, while $C$. clavata has never been reported in Europe (Farr and Rossman 2019). Curvularia clavata has been reported on a wide host range, including Oryza sativa, from which C. pseudoclavata was isolated.

Curvularia pseudoellisii Y. Marín \& Crous, sp. nov. Fig. 14.

\section{MB830061}

Etymology. Named after its morphological similarity with Curvularia ellisii.

Holotype. Sudan: on Sorghum bicolor seed (Poaceae), A.E. Elshafie, CBS H-24096.

Ex-type strain. CBS 298.80.

Asexual morph on PDA Hyphae hyaline to pale brown, branched, septate, thin-walled, 1.5-4 $\mu \mathrm{m}$. Conidiophores arising in groups, mononematous, semi- to macronematous, septate, straight to flexuous, geniculate at upper part, finely verruculose, cell size not decreasing towards apex, branched, cell walls thicker than those of vegetative hyphae, pale brown to brown, paler towards apex, not swollen at the base, $55-200 \times 3-5(7) \mu \mathrm{m}$. Conidiogenous cells finely verruculose, terminal or intercalary, proliferating sympodially, pale brown to brown, subcylindrical to swollen, $6.5-18(22) \times 3-6 \mu \mathrm{m}$. Conidia finely verruculose, mostly curved, ovoid to navicular, pale brown to brown, paler towards hilum, 0-3(4)distoseptate, $17-30 \times 8.5-13 \mu \mathrm{m}$; hila inconspicuous to slightly conspicuous, flat to slightly protuberant, darkened, thickened, 1-3.5 $\mu \mathrm{m}$ wide. Chlamydospores, microconidiation and sexual morph not observed.

Culture characteristics Colonies on PDA reaching 49-54 mm diam in 1 week, olivaceous grey to olivaceous black, with sparse aerial mycelium, lobulate, margin fimbriate; reverse olivaceous black to dark slate blue.

Notes Curvularia pseudoellisii is phylogenetically related to C. ellisii and C. neergaardii (Fig. 1). In C. pseudoellisii, the sexual morph was not observed, while the other two species produce both sexual and asexual morphs (Alcorn 1983b; Manamgoda et al. 2014). Curvularia neergaardii differs from this new species in producing subglobose to broadly ellipsoidal conidia (Fig. 8). Curvularia pseudoellisii and C. ellisii are similar in producing ovoid conidia, but can be easily distinguished by the size of the conidiophores (up to $700 \mu \mathrm{m}$ in C. ellisii vs up to $200 \mu \mathrm{m}$ in C. pseudoellisii) and the navicular conidia only present in C. pseudoellisii (Fig. 14). The three
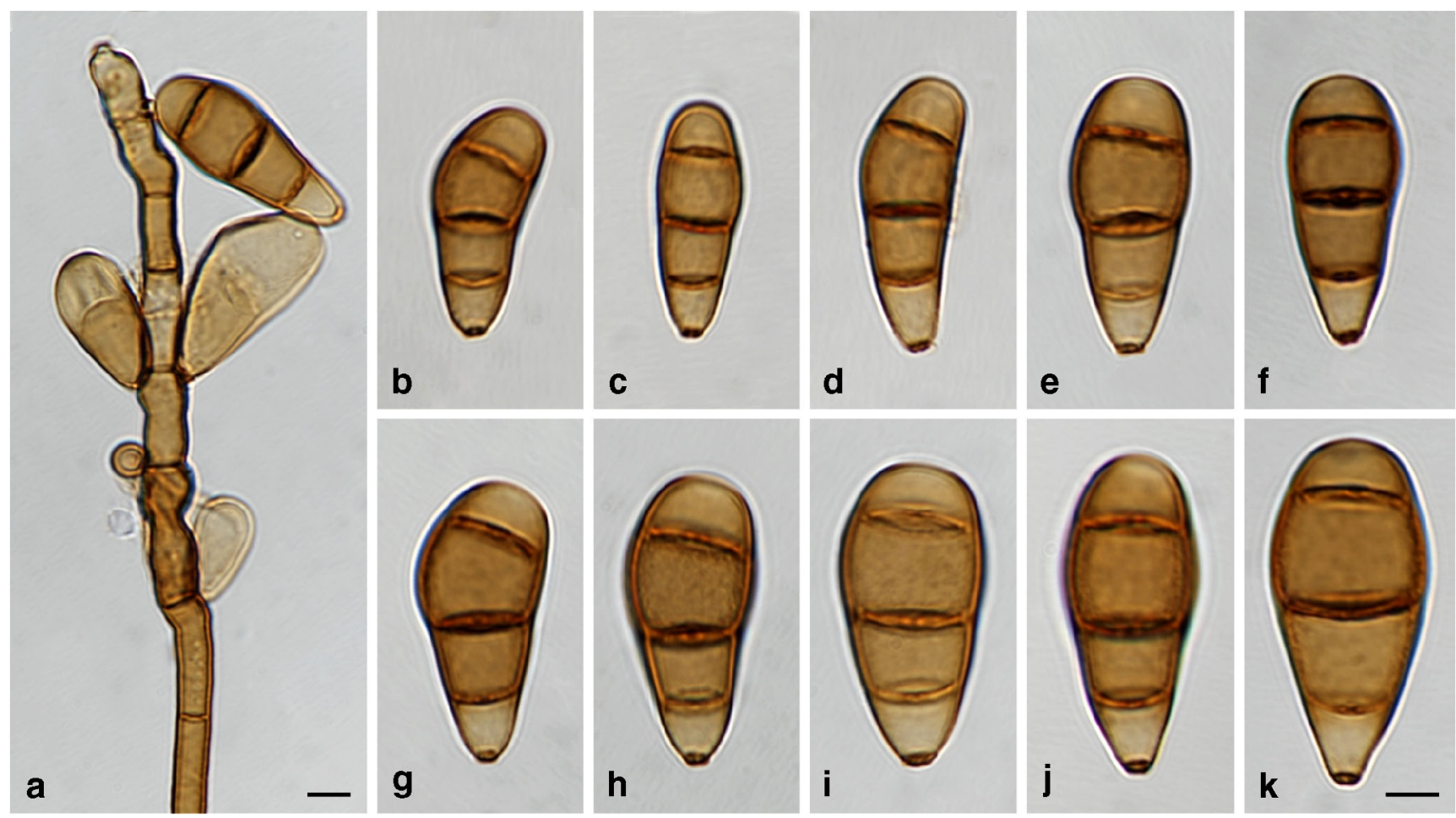

Fig. 13 Curvularia pseudoclavata (CBS 539.70 ex-type). a Conidiophore, conidiogenous cells and conidia; b-k conidia. Scale bars $5 \mu$ m, $\mathbf{k}$ applies to b-k 
species have been reported from Africa, but only C. neergaardii has been reported on Sorghum, the host from which the new species $C$. pseudoellisii was isolated.

Curvularia pseudointermedia Y. Marín \& Crous, sp. nov. Fig. 15.

\section{MB830052}

Etymology. Name based on its morphological similarity with Curvularia intermedia.

Holotype. Brazil: Pará, 200 km SE from Belém, Capitão Poço, from cultivated pasture soil, L. Pfenning, CBS H-24094.

Ex-type strain. CBS 553.89.

Additional material examined. Guadeloupe: decaying grass, unknown collector, unknown date, Plantziektekundige Dienst, CBS 188.61.
Asexual morph on PDA Hyphae hyaline to pale brown, branched, septate, 2-4.5 $\mu \mathrm{m}$. Conidiophores arising in groups, mononematous, semimacronematous, septate, straight or flexuous, rarely geniculate at upper part, sometimes cell size decreasing towards apex, branched, pale brown, paler towards apex being hyaline to subhyaline, sometimes swollen at the base, up to $520 \mu \mathrm{m}$. Conidiogenous cells smooth-walled to finely verruculose, terminal or intercalary, subhyaline to pale brown, subcylindrical to swollen, 6-25 × 4-7 $\mu \mathrm{m}$. Conidia smooth-walled to finely verruculose, straight or curved, middle cells disproportionately enlarged, ellipsoidal to ovoid, pale brown, apical cells paler than middle cells, (2)3-distoseptate, with a truly medium septum cutting the conidium transversely at its widest point, $20.5-28.5 \times 10-16 \mu \mathrm{m}$; hila
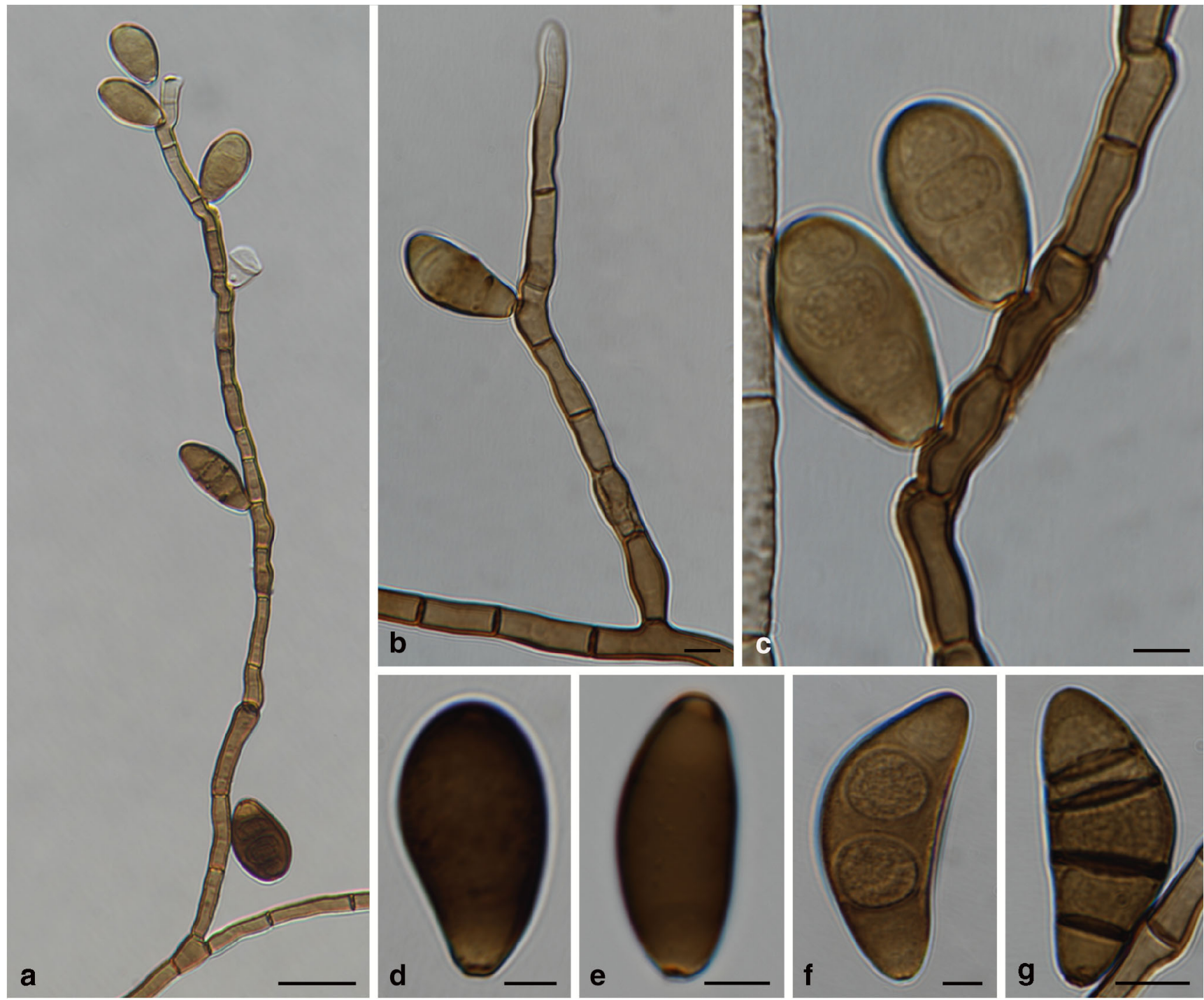

Fig. 14 Curvularia pseudoellisii (CBS 298.80 ex-type). a, b Conidiophores, conidiogenous cells and conidia; c conidiogenous cells and conidia; d-g conidia. Scale bars a $20 \mu \mathrm{m}$, all others $5 \mu \mathrm{m}$ 
inconspicuous, flat to slightly protuberant, darkened, slightly thickened, 1.5-3 $\mu \mathrm{m}$ wide. Chlamydospores, microconidiation and sexual morph not observed.

Culture characteristics Colonies on PDA covering the surface of the Petri dish in 1 week, olivaceous grey to greenish black, with abundant aerial mycelium, margin fimbriate; reverse dark slate blue.

Notes Curvularia pseudointermedia is closely related to C. arcana and C. intermedia (Fig. 1). The morphology of the asexual morph of $C$. intermedia and C. pseudointermedia is similar, producing conidia with a truly medium septum at its widest point (Sivanesan 1987). However, conidiophores and conidia are larger in C. intermedia, up to $1 \mathrm{~mm}$, and $40 \mu \mathrm{m}$, respectively (up to 520 and $28.5 \mu \mathrm{m}$ in C. pseudointermedia). Curvularia arcana can be easily distinguished from the other two species by the lack of a medium septum and disproportionally enlarged middle cells.
Curvularia pseudoprotuberata Y. Marín \& Crous, sp. nov. Fig. 16.

\section{MB830054}

Etymology. Named after its resemblance with Curvularia protuberata.

Holotype. Canada: Ontario, Puslinch, soil under Thuja occidentalis (Cupressaceae), 28 Aug. 1968, G.C. Bhatt, CBS $\mathrm{H}-24095$.

Ex-type strain. CBS 385.69.

Additional material examined. Canada: Ontario, St. Williams, soil under Pinus strobus (Pinaceae), Jul. 1966, G.C. Bhatt, CBS 550.69.

Asexual morph on PDA Hyphae subhyaline to pale brown, branched, septate, thin-walled, 2-4.5 $\mu \mathrm{m}$. Conidiophores arising in groups, mononematous, semi- to macronematous, septate, mostly flexuous, mostly geniculate at upper part, cell size
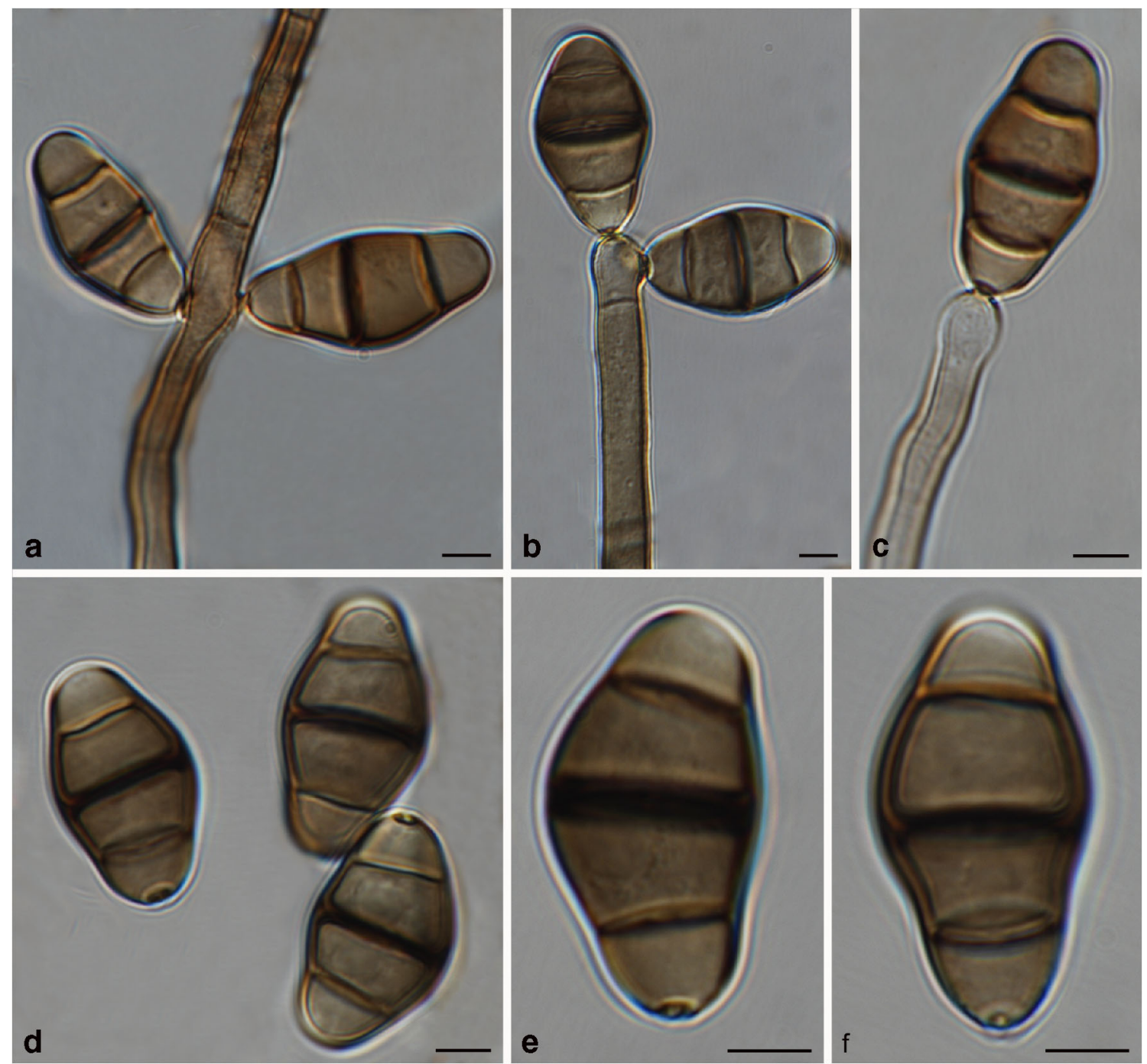

Fig. 15 Curvularia pseudointermedia (CBS 553.89 ex-type). a-c Conidiogenous cells and conidia; d-f conidia. Scale bars $5 \mu \mathrm{m}$ 
not decreasing towards apex, unbranched, cell walls thicker than those of vegetative hyphae, pale brown to brown, sometimes paler towards apex, 19-135(330) $\times(1.5) 2-5(6) \mu \mathrm{m}$. Conidiogenous cells smooth-walled to slightly verruculose, terminal or intercalary, proliferating sympodially, pale brown to brown, subcylindrical to slightly swollen, 5$13(14.5) \times 4-6 \mu \mathrm{m}$. Conidia smooth-walled to finely verruculose, straight or curved, ellipsoidal to ovoid, middle cells enlarged, pale brown to brown, apical cell paler, basal cells mostly paler, 3-4(5)-distoseptate, 19$33(35.5) \times 8-12 \mu \mathrm{m}$; hila protuberant, darkened, thickened, 1.5-3 $\mathrm{mm}$ wide. Chlamydospores, microconidiation and sexual morph not observed.

Culture characteristics Colonies on PDA covering the surface of the Petri dish in 1 week, grey olivaceous with centre smoke grey and abundant aerial mycelium giving the colony a cottony appearance, margin fimbriate; reverse dark slate blue with margin greenish grey.

Notes Curvularia pseudoprotuberata is similar and phylogenetically closely related to C. protuberata (Fig. 1). However, C. pseudoprotuberata produces longer conidia [19-33(35.5) $\mu \mathrm{m} ; 16.5-27 \mu \mathrm{m}$ in C. protuberata].
Curvularia pseudoprotuberata is represented by CBS 385.69 and CBS 550.69 (Fig. 1), both strains isolated from soil from the same location in Canada, Ontario. Curvularia protuberata has also been reported in Canada, apart from other locations in North America, South America, Africa and Europe, on a wide range of host plants included in different families (see notes under C. protuberata).

Curvularia siddiquii Y. Marín \& Crous, sp. nov. Fig. 17. MB830060

Synonym. Curvularia siddiquii S.I. Ahmed \& M. Quraishi [as 'siddiqui'], Pakistan J. Sci. Industr. Res. 3(3): 177 (1960), nom. inval., Art. 39.1 (Melbourne).

Etymology. Named after Dr. Salimuzzaman Siddiqui, who assisted Ahmad and Quraishi (1960) in the preparation of their original publication.

Holotype. Pakistan: Karachi, isolated from air, 1958, M.S. Quraishi, CBS H-12240.

Ex-type strain. CBS $196.62=$ ATCC $14861=\mathrm{IMI}$ 075861 = QM 8356.

Additional material examined: Egypt: H.M. Abdel-Fattah, CBS 142.78 .
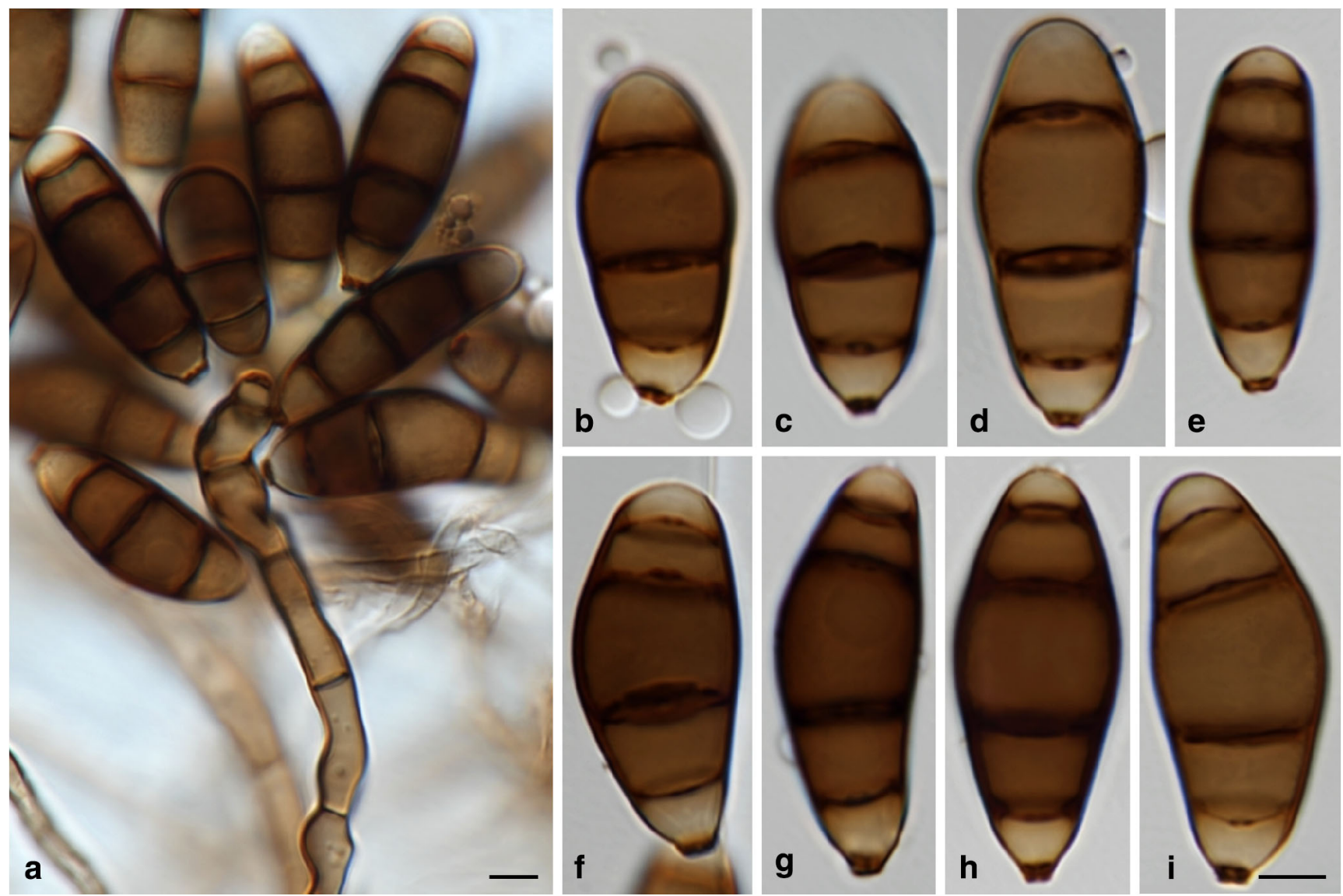

Fig. 16 Curvularia pseudoprotuberata (CBS 385.69 ex-type). a Conidiophore, conidiogenous cells and conidia; b-i Conidia. Scale bars $5 \mu \mathrm{m}, \mathbf{i}$ applies to $\mathbf{b}-\mathbf{i}$ 


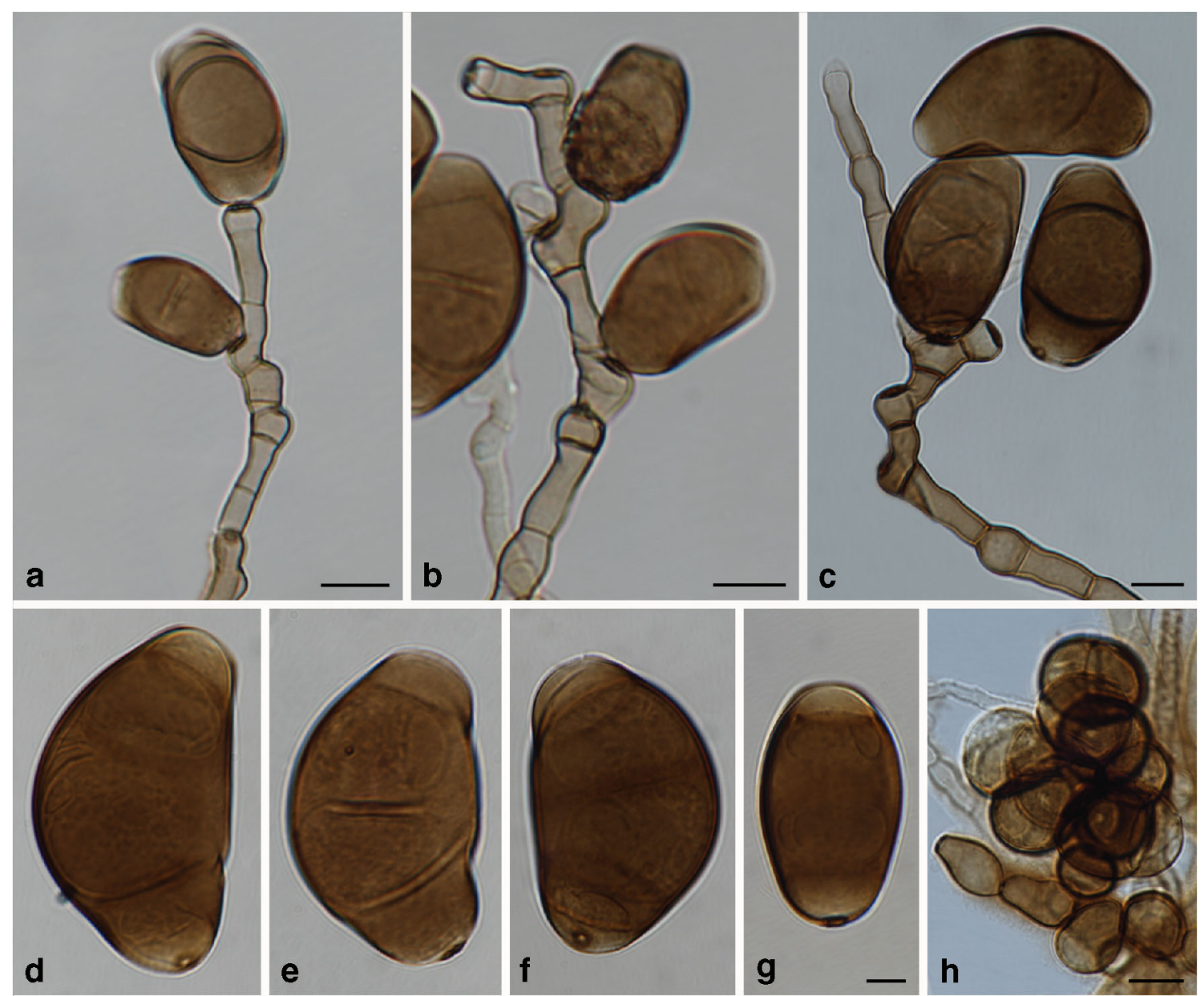

Fig. 17 Curvularia siddiquii (CBS 196.62 ex-type). a-c Conidiogenous cells and conidia; $\mathbf{d}-\mathbf{g}$ conidia; $\mathbf{h}$ chlamydospores. Scale bars $\mathbf{a}-\mathbf{c}, \mathbf{h}=10 \mu \mathrm{m} ; \mathbf{g}$ $5 \mu \mathrm{m}, \mathbf{g}$ applies to $\mathbf{d}-\mathbf{g}$

Asexual morph on PDA Hyphae hyaline to subhyaline, branched, septate, anastomosing, thin-walled, 2-4 $\mu \mathrm{m}$. Conidiophores arising in groups, mononematous, macronematous, septate, straight or flexuous, geniculate at upper part, cell size decreasing towards apex, unbranched, sometimes branched, cell walls thicker than those of vegetative hyphae, pale brown, rarely paler towards apex, not swollen at the base, up to $600 \mu \mathrm{m}$. Conidiogenous cells smooth-walled, terminal or intercalary, proliferating sympodially, pale brown, subcylindrical to swollen, 5-16(21) $\times 6.5-8.5 \mu \mathrm{m}$. Conidia smooth-walled, curved, rarely straight, middle cells disproportionately enlarged, navicular, rarely ellipsoidal, pale brown to brown, sometimes apical cells paler than middle cells being subhyaline, (1)2-3(4)-distoseptate, (21.5)24-40 × (15)17$23 \mu \mathrm{m}$; hila inconspicuous to slightly conspicuous, flat to slightly protuberant, darkened, slightly thickened, 2-4 $\mu \mathrm{m}$ wide. Chlamydospores globose to subglobose or cylindrical, brown, thick-walled, terminally and intercalary, $8.5-22.5 \mu \mathrm{m}$ diam. Microconidiation and sexual morph not observed.

Culture characteristics Ex-type strain CBS 196.62: Colonies on PDA reaching 64-71 mm diam in 1 week, apricot to chestnut, fasciculate, irregular form, margin fimbriate; reverse umber to chestnut. Strain CBS 142.78: Colonies on PDA attaining 52-62 mm diam in 1 week, olivaceous, mouse grey and white in the centre, cottony, raised, margin fimbriate; reverse olivaceous to fuscus olivaceous, margin buff.

Notes Curvularia siddiquii was introduced by Ahmad and Quraishi (1960) to accommodate a fungus isolated from air in Pakistan. However, this species is invalid due to the lack of a Latin description. Subsequently, Ellis (1971) synonymised C. siddiquii with Drechslera papendorfii, which clusters in Curvularia (Marin-Felix et al. 2017a) where it was initially described (van der Aa 1967). This synonymy was not molecularly corroborated since no sequence data were available at that moment. In the phylogenetic tree generated here (Fig. 1), the ex-type strains of $C$. siddiquii (CBS 196.62) and C. papendorfii (CBS 308.67) formed two separate lineages, representing two distinct species from other Curvularia spp. Therefore, we resurrected the former taxon as a new species. Morphologically, C. siddiquii can be distinguished from C. papendorfii by the length of its conidiophores (up to $200 \mu \mathrm{m}$ in $C$. papendorfii vs up to $600 \mu \mathrm{m}$ in $C$. siddiquii) and the production of chlamydospores, which have not been observed in C. papendorfii. 

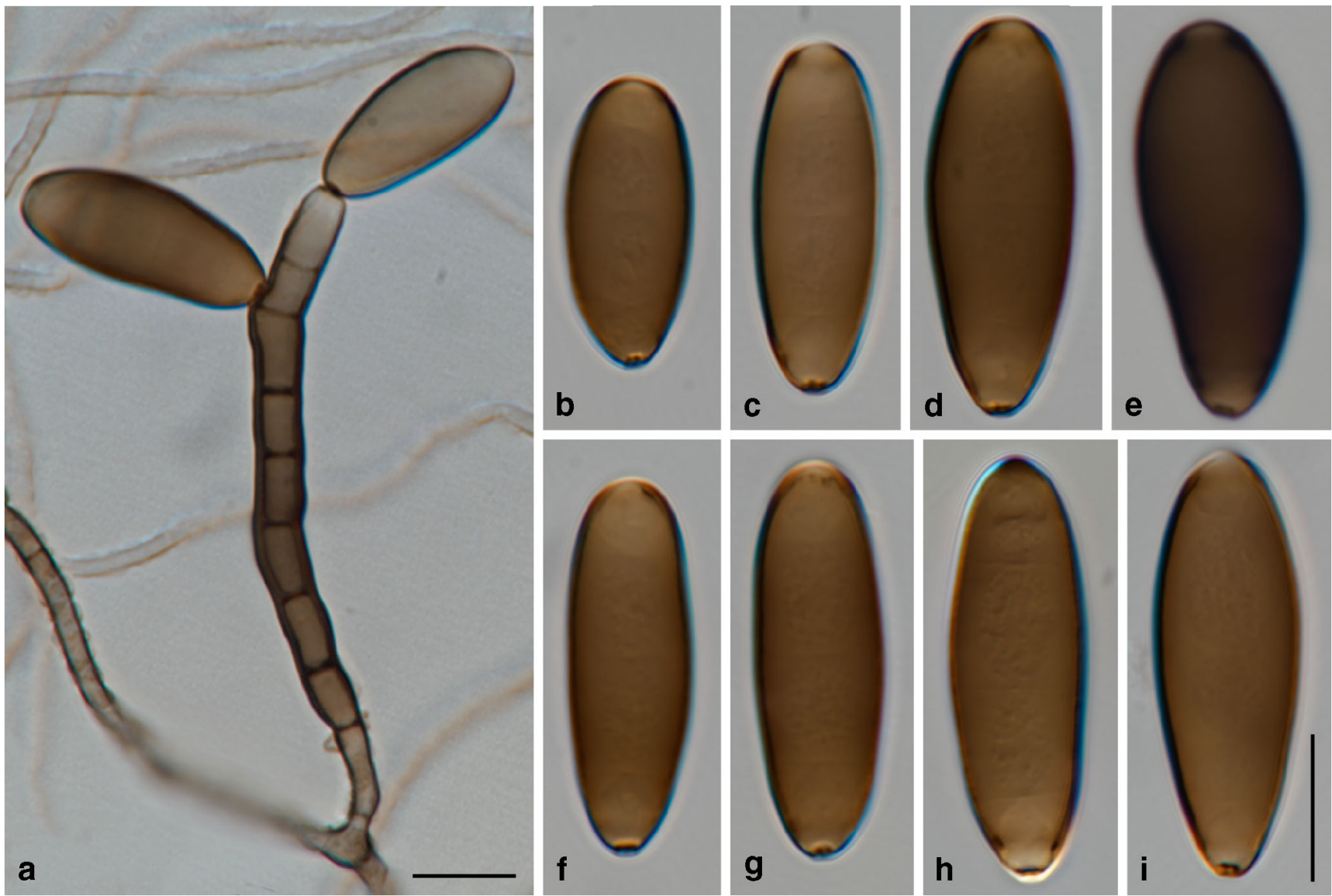

Fig. 18 Curvularia tribuli (CBS 126975 ex-type). a Conidiophore, conidiogenous cells and conidia; b-i Conidia. Scale bars $10 \mu \mathrm{m}$, i applies to b-i

Curvularia papendorfii has been reported from soil and on various genera of Poaceae, causing leaf spots (Farr and Rossman 2019), while the type material of C. siddiquii was isolated from air, and the substrate of the second strain belonging to this species is unknown. Both species have been reported only in Asia and Africa, respectively.

Curvularia tribuli Hern.-Restr. \& Y. Marín, sp. nov. Fig. 18.

\section{MB830062}

Etymology. Name refers to Tribulus, the host genus from which this fungus was collected.

Holotype. South Africa: Cape Province, on Tribulus terrestris leaf (Zygophyllaceae), Aug. 1971, coll. W.F.O. Marasas, CBS H-24097.

Ex-type strain. CBS $126975=$ CCFC000890 $=$ DAOMC 137386

Asexual morph on PDA Hyphae pale brown to brown, branched, septate, smooth-walled to verrucose, thick-walled, 1.5-3(4.5) $\mu \mathrm{m}$. Conidiophores arising in groups, mononematous, semi- to macronematous, septate, straight to flexuous, rarely geniculate at upper part, cell size not decreasing towards apex, unbranched, cell walls thicker than those of vegetative hyphae, brown to dark brown, paler towards the apex, not swollen at the base, 15.5-104 × 4-6.5 $\mu \mathrm{m}$. Conidiogenous cells smooth-walled, terminal or intercalary, proliferating sympodially, pale brown to brown, subcylindrical to slightly swollen, 6.514 × 4-5(7) $\mu \mathrm{m}$. Conidia smooth-walled, straight, rarely curved, ellipsoidal to ovoid, pale brown to brown, mostly paler at base, sometimes paler at apex, 1-4(6)-distoseptate, 17-30 $\times 8.5$ $13 \mu \mathrm{m}$; hila flat, darkened, slightly thickened, $1-2 \mu \mathrm{m}$ wide. Chlamydospores, microconidiation and sexual morph not observed.

Culture characteristics Colonies on PDA reaching 41$53 \mathrm{~mm}$ diam in 1 week, olivaceous grey to olivaceous black, with abundant aerial mycelium giving the colony a cottony appearance, convex, margin fimbriate; reverse olivaceous black.

Notes In our phylogenetic study, C. tribuli was located on an independent branch far from other species of the genus (Fig. 1). This is the first species of Curvularia reported on Tribulus terrestris (Zygophyllaceae).

Curvularia verruciformis G.P. Agarwal \& V.P. Sahni, Curr. Sci. 32: 277 (1963). Fig. 19.

Holotype. India: Jabalpur, from Triticum, 20 Mar. 1962, G.P. Agarwal, IMI 92671. 

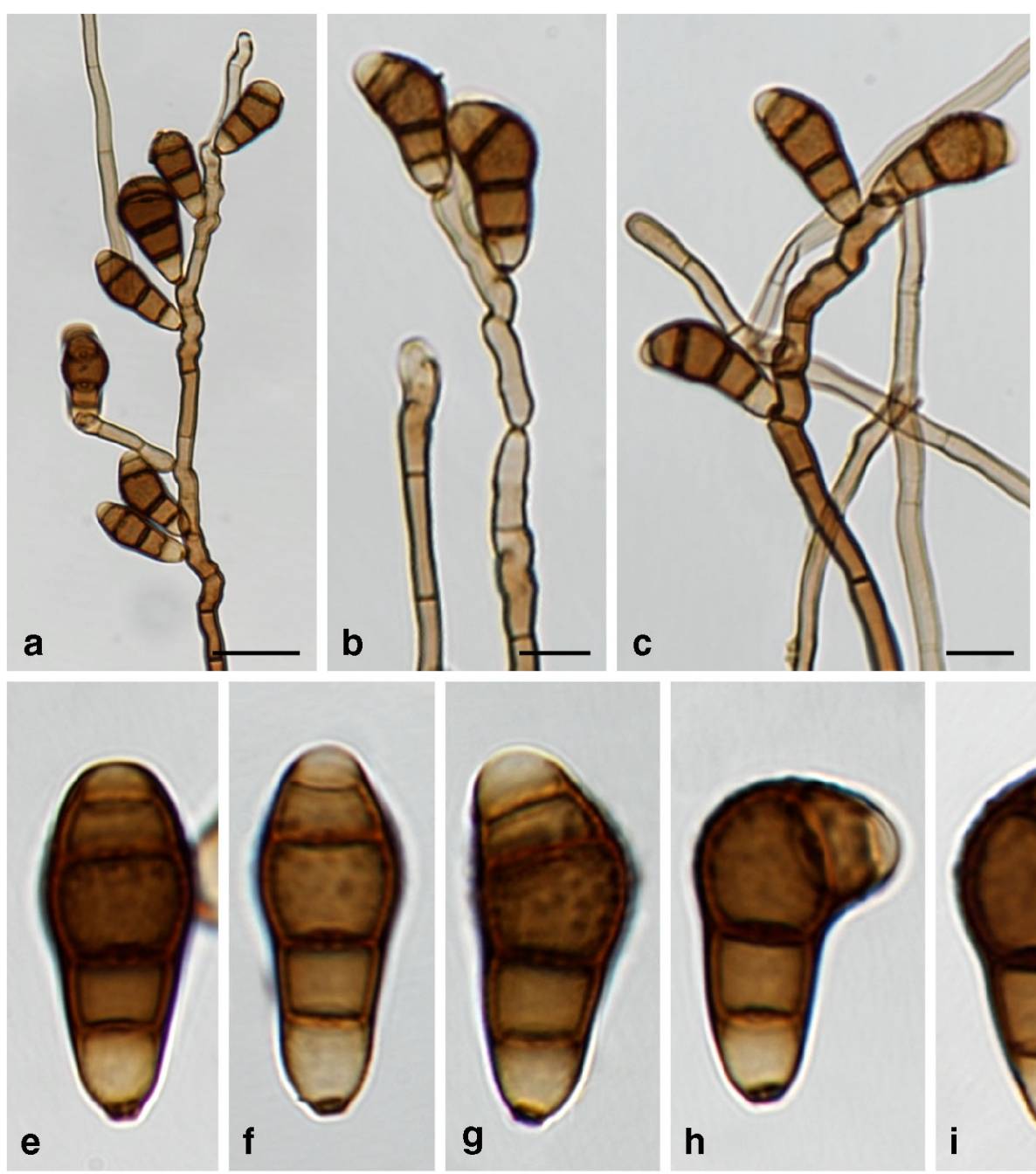
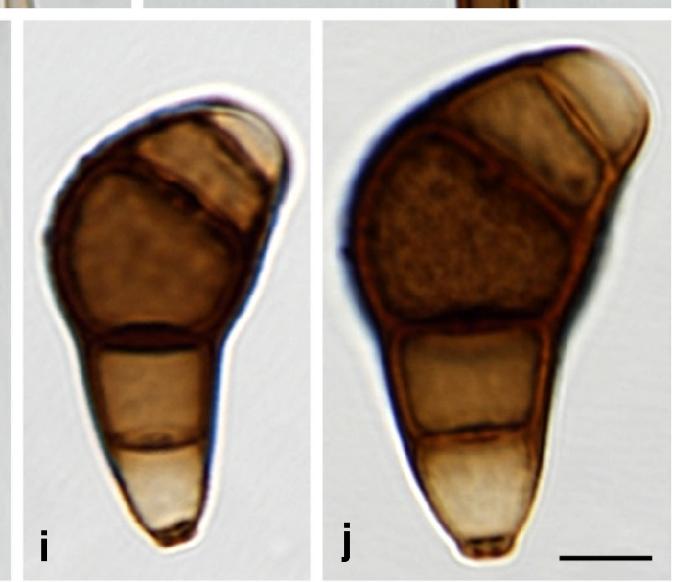

Fig. 19 Curvularia verruciformis (CBS 537.75). a-c Conidiophores, conidiogenous cells and conidia; $\mathbf{d}$ conidiogenous cells and conidia; $\mathbf{e - j}$ conidia. Scale bars a $20 \mu \mathrm{m} ; \mathbf{b}, \mathbf{c} 10 \mu \mathrm{m} ; \mathbf{d}, \mathbf{j} 5 \mu \mathrm{m}$, japplies to $\mathbf{e}-\mathbf{j}$

Material examined. New Zealand: Mitchell River, from Lobibyx (masked plover) feather, 17 Apr. 1965, J.L. Alcorn, CBS 537.75.

Asexual morph on PDA Hyphae subhyaline to pale brown, branched, septate, thick-walled, 2-4.5 $\mu \mathrm{m}$. Conidiophores arising single or in groups, mononematous, semi- to macronematous, septate, straight or flexuous, geniculate at upper part, branched, cell walls thicker than those of vegetative hyphae, pale brown, paler towards apex, mostly swollen at the base, $40-500 \times 3.5-6(7.5) \mu \mathrm{m}$. Conidiogenous cells smooth-walled, terminal or intercalary, proliferating sympodially, pale brown, subcylindrical to swollen, 6$17.5 \times 3-6 \mu \mathrm{m}$. Conidia verrucose, mostly curved, sometimes geniculate, ellipsoidal to ovoid or clavate, middle cells disproportionately enlarged, pale brown to brown, apical and basal cells paler, (3)4-distoseptate, 20-27.5 × 8-12 $\mu \mathrm{m}$; hila protuberant, darkened, slightly thickened, 1.8-3.2 $\mu \mathrm{m}$ wide. Chlamydospores, microconidiation and sexual morph not observed.
Notes Curvularia verruciformis is morphologically similar to C. verrucosa and C. verruculosa since all three species produce verrucose conidia. However, they differ in the number of conidial septa being mostly 3-distoseptate in C. verruculosa and 4-distoseptate in C. verruciformis and C. verrucosa (Ellis 1966; Sivanesan 1992). The conidia of C. verrucosa and C. verruculosa are wider (14-18 and 12-17 $\mu \mathrm{m}$, respectively) than in $C$. verruciformis due to the middle cell being more enlarged. Conidia in C. verruciformis tend to be more geniculate which makes the longitude of the conidia shorter than in C. verruculosa (20-27.5 $\mu \mathrm{m}$ in C. verruciformis vs $20-35 \mu \mathrm{m}$ in $C$. verruculosa). Curvularia verrucosa also produces more geniculate conidia than $C$. verruculosa, but these are longer than in the other two species $(27-40 \mu \mathrm{m})$. Phylogenetically, these species are very distant (Fig. 1).

The closest relative of $C$. verruciformis is $C$. uncinata (Fig. 1), but both species can be easily distinguished by the ornamentation of the conidia, being smooth-walled in C. uncinata and verrucose in C. verruciformis (Sivanesan 1987). 
Curvularia verruciformis causes root rot of wheat in India (Agarwal and Sahni 1963). Curvularia uncinata and $C$. verruculosa have also been reported from this host and location, while $C$. verrucosa has been reported in India, but never from wheat (Farr and Rossman 2019). However, the strain included in the molecular study was isolated from Lobibyx in New Zealand, a substrate and location not reported for the other three species.

\section{Discussion}

Curvularia is morphologically similar to the helminthosporioid genus Bipolaris, the main difference being the conidial curvature and length. Species in both genera present intermediate morphology, making sequence data necessary to properly delineate both genera. Recent phylogenetic studies based on ITS, GAPDH and TEF1 demonstrated that some species placed in Bipolaris belonged to Curvularia, and vice versa (Manamgoda et al. 2014, 2015; Tan et al. 2014). In the present study, an additional new combination is proposed in Curvularia to accommodate B. cactivora.

The genus Pyrenophora also produces an asexual morph similar to that of Bipolaris and Curvularia. The asexual morph was known as Drechslera, but its synonymy was recently discussed (Rossman et al. 2015). Although some species have already been transferred to Pyrenophora (Ariyawansa et al. 2014; Marin-Felix et al. 2019), there are still a large number of species which await treatment. The main problem encountered is the lack of type or reference material of Drechslera spp. While the sexual morph of Pyrenophora can be easily distinguished from that of Curvularia by its muriformly septate ascospores, the asexual morphs are similar. DNA sequence data therefore remain essential to properly delineate both genera. In the present study, D. patereae is newly combined in Curvularia since this genus accommodated the ex-type strain of this species.

Exserohilum is another graminicolous genus related to Curvularia. Historically, Exserohilum was delimited based on its conidia having protuberant hila (Alcorn 1983a; Sivanesan 1987). However, in some Curvularia species, the hilum is also protruding, differing from that of Exserohilum in being separated from the conidial body by a septum (Hernández-Restrepo et al. 2018). This resemblance led to the wrong allocation of some species to Exserohilum, which were subsequently transferred to Curvularia, as in the case of C. micropus, C. sorghicola (Hernández-Restrepo et al. 2018) and C. heteropogonicola (Alcorn 1991). Another example is C. crassiseptata, which was originally introduced as E. inaequale (Zhang et al. 2004). Recently, the placement of this species in Curvularia was molecularly demonstrated by Hernández-Restrepo et al. (2018). In the present study, the morphological study of the ex-type strain was conducted, providing a description and illustrations of the type material. This species produces conidia with protuberant hila similar to those found in Exserohilum spp., and therefore, DNA sequence data are necessary to properly delineate these two genera.

Species delimitation in Curvularia remains problematic due to the overlapping morphological characters among many species (Manamgoda et al. 2015; Marin-Felix et al. 2017b). Therefore, sequence data are essential for an accurate identification of species, with ITS, GAPDH and TEF1 being the loci selected for this purpose (Marin-Felix et al. 2017a), although the ITS and GAPDH alone can also resolve the majority of taxa in Curvularia (Manamgoda et al. 2015). Sequences of $R P B 2$ are also available for some Curvularia species and were used in previous phylogenetic studies (Madrid et al. 2014; Hernández-Restrepo et al. 2018), but it has not been included as barcode for delimiting species of Curvularia due to the general lack of $R P B 2$ data for most taxa (Marin-Felix et al. 2017a). Our phylogenetic study based on ITS, GAPDH and TEF1 sequences demonstrated that 15 strains housed in the Westerdijk Fungal Biodiversity Institute collection represent 10 different species, i.e. C. austriaca, C. canadensis, C. ellisii, C. pseudoclavata, C. pseudoellisii, C. pseudointermedia, C. pseudoprotuberata, C. siddiquii and C. tribuli. Curvularia canadensis, C. ellisii, C. pseudoclavata, C. pseudoellisii and C. tribuli were isolated from plant hosts, all of them being members of the Poaceae, which is the common host family of Curvularia spp., except for C. tribuli, which was isolated from Tribulus terrestris (Zygophyllaceae). Curvularia austriaca has been exclusively isolated from human clinical specimens, i.e. nasal cavity, corneal ulcer and peritoneal dialysis fluid. Other Curvularia spp. were previously associated with clinical samples, e.g. C. australiensis, C. hawaiiensis, C. lunata and C. spicifera (da Cunha et al. 2013). These taxa are considered potential opportunistic pathogens, causing respiratory tract, cutaneous, cerebral and corneal infections, mainly in immunocompromised patients (McGinnis et al. 1986; Carter and Boudreaux 2004; Madrid et al. 2014). Curvularia pseudointermedia and C. pseudoprotuberata were isolated from soil. Several species were previously isolated from this substrate (Watanabe 2002; Manamgoda et al. 2011, 2015; Marin-Felix et al. 2017a), demonstrating that soil is a reservoir for Curvularia species. Finally, $C$. ellisii and $C$. siddiquii, both validated in this study, were isolated from air.

Curvularia sichuanensis (Zhang et al. 2007) was not included in previous phylogenetic studies (Manamgoda et al. 2014; Marin-Felix et al. 2017a, b), although the ITS sequence of the ex-type strain was available. In our phylogenetic study, it clustered close to $C$. akaii and $C$. akaiiensis. The ITS sequence showed only one nucleotide difference with respect to C. akaiiensis and three compared to C. akaii. Although the 
ITS regions alone can resolve the majority of taxa in Curvularia (Manamgoda et al. 2015), sequences of GAPDH and $T E F 1$ are needed to clarify if it is a different species. Therefore, the synonymy of $C$. sichuanensis with $C$. akaii remains unconfirmed.

Curvularia chlamydospora and C. pseudolunata, both clinical species associated with nasal sinus and C. chlamydospora also found in a toenail (Madrid et al. 2014), clustered together in the same well-supported clade (100\% bs/0.99 pp) without phylogenetic distance. Although ITS and GAPDH sequences of the ex-type strains showed $100 \%$ nucleotide similarity, these species can be distinguished based on RPB2 sequences, which had only $94.91 \%$ nucleotide similarity. Another two species located in the same wellsupported clade ( $100 \% \mathrm{bs} / 1 \mathrm{pp}$ ) without phylogenetic distance are $C$. harveyi and C. gudauskasii. However, DAOMC 165085 , which is the strain identified as C. gudauskasii in previous phylogenetic studies (Berbee et al. 1999; MarinFelix et al. 2017a, b), was not morphologically studied in any previous study, and it was deposited in DAOMC collection as $C$. trifolii. Therefore, the status of this species remains uncertain. Curvularia borreriae and C. pallescens were also located in the same clade ( $72 \% \mathrm{bs} / 0.98 \mathrm{pp})$. According to the descriptions provided by Sivanesan (1987), these species are similar, differing mainly in the colour of the conidia, being almost concolorous in C. pallescens and brown or dark brown in C. borreriae. However, the strain CBS 859.73, identified as C. borreriae in previous phylogenetic studies (da Cunha et al. 2013; Marin-Felix et al. 2017a, b; Hernández-Restrepo et al. 2018), is not ex-type and proved to be sterile, making morphological comparisons impossible. Therefore, the potential synonymy of these species remains unresolved.

Curvularia ahvazensis was isolated from rotten roots of Zinnia elegans in Iran (Mehrabi-Koushki et al. 2018). The ex-type strain of this species clustered in an independent branch with a long distance (Fig. 1). Surprisingly, the GAPDH and TEF1 sequences showed a nucleotide similarity higher than $99 \%$ with different Curvularia spp., but the ITS sequence presented only $95 \%$ nucleotide similarity with the closest species, i.e. C. hawaiiensis and C. sorokiniana. Considering that the ITS has more constant characters (Manamgoda et al. 2015) and tends to show less nucleotide variability between different species than GAPDH (Tan et al. 2018), this sequence needs to be redone to verify if it is correct, and confirm if $C$. ahvazensis is a distinct species. According to our phylogenetic and morphological studies, and the new species and combinations proposed, as well as the synonymy performed, the genus Curvularia presently comprises 118 accepted species. However, there are still numerous species that lack molecular data and in a high number of cases due to the lack of type material. Therefore, it is of utmost importance to recollect material of these taxa, and designate epi- or neotypes to secure the application of these names. In this context, an epitype and ex-epitype culture for C. oryzae-sativae is designated here from a strain that morphologically fits with the original description and was isolated from the same host in the same location to that of the holotype.

Acknowledgements Yasmina Marin-Felix is grateful for the postdoctoral stipendium received from the Alexander-von-Humboldt Foundation, Germany. We thank the curators Yu Pei Tan (BRIP), Tara Rintoul (DAOMC), Bevan Weir (ICMP and PDD) and Dagmar Triebel (Botanische Staatssammlung München) for their assistance with information of some strains. We also like to thank Dr. Alberto Miguel Stchigel Glikman (Mycology Unit, Medical School and IISPV) and Karina A. Presta [Biblioteca Conjunta, Facultad de Ciencias Agrarias y Forestales $\mathrm{y}$ de Ciencias Veterinarias (FCAyF-FCV)] for providing literature used in the present study.

Funding Information Open Access funding provided by Projekt DEAL.

Open Access This article is licensed under a Creative Commons Attribution 4.0 International License, which permits use, sharing, adaptation, distribution and reproduction in any medium or format, as long as you give appropriate credit to the original author(s) and the source, provide a link to the Creative Commons licence, and indicate if changes were made. The images or other third party material in this article are included in the article's Creative Commons licence, unless indicated otherwise in a credit line to the material. If material is not included in the article's Creative Commons licence and your intended use is not permitted by statutory regulation or exceeds the permitted use, you will need to obtain permission directly from the copyright holder. To view a copy of this licence, visit http://creativecommons.org/licenses/by/4.0/.

\section{References}

Agarwal GP, Sahni VP (1963) Curvularia verruciformis Agarwal and Sahni. A new fungus from Jabalpur (M. P). Curr Sci 32:276-277

Ahmad SI, Quraishi MS (1960) Two new species of genus Curvularia. Curvularia siddiqui sp. nov. and Curvularia ellisi sp. nov. Pak J Sci Ind Res 3:177-178

Alcorn JL (1983a) Generic concepts in Drechslera, Bipolaris and Exserohilum. Mycotaxon 17:1-86

Alcorn JL (1983b) Cochliobolus ellisii sp. nov. Trans Br Mycol Soc 81: $172-174$

Alcorn JL (1990) Additions to Bipolaris, Cochliobolus and Curvularia. Mycotaxon 39:361-392

Alcorn JL (1991) Combinations and synonymy in Bipolaris and Curvularia, and a new species of Exserohilum. Mycotaxon 41: 329-343

Ariyawansa HA, Kang JC, Alias SA et al (2014) Pyrenophora. Mycosphere 5:351-362

Berbee ML, Pirseyedi M, Hubbard S (1999) Cochliobolus phylogenetics and the origin of known, highly virulent pathogens, inferred from ITS and glyceraldehyde-3-phosphate dehydrogenase gene sequences. Mycologia 91:964-977

Carranza MR (1983) Una nueva especie del genero Drechslera sobre granos de trigo candeal. Revista Fac Agron Univ Nac La Plata 59:65-70

Carter E, Boudreaux C (2004) Fatal cerebral phaeohyphomycosis due to Curvularia lunata in an immunocompetent patient. J Clin Microbiol 42:5419-5423

Crous PW, Gams W, Stalpers JA et al (2004) MycoBank: an online initiative to launch mycology into the 21st century. Stud Mycol 50:19-22 
Crous PW, Verkley GJM, Groenewald JZ et al (2019) Westerdijk laboratory manual series 1: fungal biodiversity. Westerdijk Fungal Biodiversity Institute, Utrecht

da Cunha KC, Sutton DA, Fothergill AW et al (2013) In vitro antifungal susceptibility and molecular identity of 99 clinical isolates of the opportunistic fungal genus Curvularia. Diagn Microbiol Infect Dis $76: 168-174$

Danquah OA (1975) Two new species of Drechslera. Trans Br Mycol Soc 64:544-546

de Hoog GS, Guarro J, Gene J et al (2011) Atlas of clinical Fungi, CD-ROM version 3.1. CBS-KNAW Fungal Biodiversity Centre, Utrecht

Dehdari F, Mehrabi-Koushki M, Hayati J (2018) Curvularia shahidchamranensis sp. nov., a crude oil-tolerant fungus. Curr Res Environ Appl Mycol 8:572-584

Ellis MB (1966) Dematiaceous hyphomycetes. VII. Curvularia, Brachysporium, etc. Mycol Pap 106:1-57

Ellis MB (1971) Dematiaceous Hyphomycetes. Commonwealth Mycological Institute, Kew

Farr DF, Rossman AY (2019) Fungal databases, U.S. National Fungus Collections, ARS, USDA. from https://nt.ars-grin.gov/ fungaldatabases/. Accessed 24 January 2019

Garibaldi A, Bertetti D, Pensa P et al (2014) First report of stem rot on Cereus peruvianus monstruosus caused by Bipolaris cactivora (Petr.) Alcorn in Italy. Plant Dis 98:159

Heidari K, Mehrabi-Koushki M, Farokhinejad R (2018) Curvularia mosaddeghii sp. nov., a novel species from the family Pleosporaceae. Mycosphere 9:635-646

Hernández-Restrepo M, Groenewald JZ, Elliott ML et al (2016) Take-all or nothing. Stud Mycol 83:19-48

Hernández-Restrepo M, Madrid H, Tan YP et al (2018) Multi-locus phylogeny and taxonomy of Exserohilum. Persoonia 41:71-108

Hyde KD, Norphanphoun C, Abreu VP et al (2017) Fungal diversity notes 603-708: taxonomic and phylogenetic notes on genera and species. Fungal Divers 87:1-235

Katoh K, Standley DM (2013) MAFFT multiple sequence alignment software v. 7: improvements in performance and usability. Mol Biol Evol 30:772-780

Khasanov BA (1992) Opredelitel' Gribov-Vozbuditelei 'Gel'mintosporiozov' Rastenii iz Rodov Bipolaris, Drechslera i Exserohilum. Izdatel'stvo 'Fan' Akademii Nauk, Tashkent

Liang Y, Ran SF, Bhat J et al (2018) Curvularia microspora sp. nov. associated with leaf diseases of Hippeastrum striatum in China. Mycokeys 29:49-61

Madrid H, da Cunha KC, Gené J et al (2014) Novel Curvularia species from clinical specimens. Persoonia 33:48-60

Manamgoda DS, Cai L, Bahkali AH et al (2011) Cochliobolus: an overview and current status of species. Fungal Divers 51:3-42

Manamgoda DS, Cai L, McKenzie EHC et al (2012) A phylogenetic and taxonomic re-evaluation of the Bipolaris - Cochliobolus Curvularia complex. Fungal Divers 56:131-144

Manamgoda DS, Rossman AY, Castlebury LA et al (2014) The genus Bipolaris. Stud Mycol 79:221-288

Manamgoda DS, Rossman AY, Castlebury LA et al (2015) A taxonomic and phylogenetic re-appraisal of the genus Curvularia (Pleosporaceae): human and plant pathogens. Phytotaxa 212:175198

Marin-Felix Y, Groenewald JZ, Cai L et al (2017a) Genera of phytopathogenic fungi: GOPHY 1. Stud Mycol 86:99-216

Marin-Felix Y, Senwanna C, Cheewangkoon R et al (2017b) New species and records of Bipolaris and Curvularia from Thailand. Mycosphere 8:1556-1574

Marin-Felix Y, Hernández-Restrepo M, Iturrieta-González I et al (2019) Genera of phytopathogenic fungi: GOPHY 3. Stud Mycol 94:1-124
McGinnis MR, Rinaldi MG, Winn RE (1986) Emerging agents of phaeohyphomycosis: pathogenic species of Bipolaris and Exserohilum. J Clin Microbiol 24:250-259

Mehrabi-Koushki M, Pooladi P, Eisvand P et al (2018) Curvularia ahvazensis and C. rouhanii spp. nov. from Iran. Mycosphere 9: $1173-1186$

Miqueleiz Zapatero A, Hernando C, Barba J et al (2018) First report of a case of fungal keratitis due to Curvularia hominis in Spain. Rev Ibéroam Micol 35:155-158

Nelson RR (1965) A new species of Curvularia with a protuberant conidial hilum. Mycologia 57:822-825

Petrak F (1931) Beiträge zur Kenntnis einiger Pilzkrankheiten der Kakteen. Gartenbauwissenschaft 5:226-249

Rayner RW (1970) A mycological colour chart. Commonwealth Mycological Institute, Kew

Rossman AY, Crous PW, Hyde KD et al (2015) Recommended names for pleomorphic genera in Dothideomycetes. IMA Fungus 6:507-523

Sivanesan A (1984) New species of Exserohilum. Trans Br Mycol Soc 83:319-329

Sivanesan A (1987) Graminicolous species of Bipolaris, Curvularia, Drechslera, Exserohilum and their teleomorphs. Mycol Pap 158: $1-261$

Sivanesan A (1992) New Bipolaris, Curvularia and Exserohilum species. Mycol Res 96:485-489

Tamura K, Stecher G, Peterson D et al (2013) MEGA6: molecular evolutionary genetics analysis version 6.0. Mol Biol Evol 30:27252729

Tan YP, Madrid H, Crous PW et al (2014) Johnalcornia gen. et. comb. nov., and nine new combinations in Curvularia based on molecular phylogenetic analysis. Australas Plant Pathol 43:589-603

Tan YP, Crous PW, Shivas RG (2018) Cryptic species of Curvularia in the culture collection of the Queensland plant pathology herbarium. MycoKeys 35:1-25

Tarnowski TLB, Palmateer AJ, Crane JH (2010) First report of fruit rot on Hylocereus undatus caused by Bipolaris cactivora in South Florida. Plant Dis 94:1506

Tibpromma S, Hyde KD, McKenzie EHC et al (2018) Fungal diversity notes 840-928: micro-fungi associated with Pandanaceae. Fungal Divers 93:1-160

van der Aa HH (1967) A new species of Curvularia. Persoonia 5:45-46

Vasikasin V, Nasomsong W, Srisuttiyakorn C et al (2019) Disseminated phaeohyphomycosis caused by Curvularia tuberculata in a previously healthy man. Mycopathologia 184:321-325

Verma P, Singh S, Singh R (2013) Seven species of Curvularia isolated from three lakes of Bhopal. Adv Life Sci Technol 8:13-15

Wang H, Xu L, Zhang Z et al (2019) First report of Curvularia pseudobrachyspora causing leaf spots in Areca catechu in China. Plant Dis 103:150

Watanabe T (2002) Pictorial atlas of soil and seed fungi: morphologies of cultured fungi and key to species, 2nd edn. CRC, Boca Ratón

White TJ, Bruns TD, Lee S et al (1990) Amplification and direct sequencing of fungal ribosomal genes for phylogenetics. In: Gelfand $\mathrm{M}$, Sninsky JI, White TJ (eds) PCR protocols: a guide to methods and applications. Academic, New York, pp 315-322

Zhang M, Zhang TY, Wu WP (2004) A new name and a new variety in Curvularia. Mycosystema 23:177-178

Zhang M, Wu HY, Pei ZY et al (2007) A new species and a new variety of Curvularia in China. S W China J Agric Sci 20:1144-1145

Publisher's note Springer Nature remains neutral with regard to jurisdictional claims in published maps and institutional affiliations. 